\title{
Lactobacillus-Based Probiotics Reduce the Adverse Effects of Stress in Rodents: A Meta-analysis
}

\author{
Claire Mindus, Jennifer Ellis, Nienke van Staaveren and Alexandra Harlander-Matauschek* \\ Department of Animal Biosciences, University of Guelph, Guelph, ON, Canada
}

Lactobacillus species play a critical role in the bidirectional communication between the gut and the brain. Consequently, they have the potential to aid in the treatment of psychological disorders. The impact of Lactobacillus supplementation on the stress responses triggering psychological disorders has not been systematically reviewed. Therefore, the aim of this meta-analysis is to summarize the body of research assessing the effects of Lactobacillus-based probiotics in rodents that underwent an experimental stress treatment or not. The duration of immobility in a Forced Swim Test (FST) was

OPEN ACCESS

Edited by:

Caio Maximino,

Federal University of South and Southeast of Pará, Brazil

Reviewed by: Juan Francisco Rodríguez-Landa, Universidad Veracruzana, Mexico Jonathan Cueto-Escobedo, Universidad Veracruzana, Mexico Cilene Lino-de-Oliveira, Federal University of Santa Catarina, Brazil

${ }^{*}$ Correspondence: Alexandra Harlander-Matauschek aharland@uoguelph.ca

Specialty section:

This article was submitted to Emotion Regulation and Processing,

a section of the journal

Frontiers in Behavioral Neuroscience

Received: 16 December 2020 Accepted: 19 May 2021

Published: 16 June 2021

Citation:

Mindus C, Ellis J, van Staaveren N and Harlander-Matauschek A (2021)

Lactobacillus-Based Probiotics Reduce the Adverse Effects of Stress

in Rodents: A Meta-analysis.

Front. Behav. Neurosci. 15:642757.

doi: 10.3389/fnbeh.2021.642757 the outcome used to measure changes induced by various treatments. Four online databases were systematically searched for relevant studies published in English. Fourteen studies meeting the criteria were included in the meta-analysis. The effects of probiotic supplementation and stress treatment on the duration of immobility in the FST were analyzed using a generalized linear mixed model. Publication bias was evaluated by funnel plots. Our analysis shows that Lactobacillus-based probiotic supplements significantly reduce immobility in the FST $(P<0.001)$ in stressed rodents. However, probiotics did not affect the rodents that did not undergo the stress treatment $(P=0.168)$. These findings provide a better understanding of the potential of Lactobacillus-based probiotics for the management of stress-induced behavior.

Keywords: meta-analysis, probiotic, Lactobacillus, stress, psychological disorder, gut-brain axis

\section{INTRODUCTION}

Lactobacillus species have a long history of use by humans (Holzapfel, 2002) and are considered safe by the World Health Organization (WHO and FAO, 2006). For example, Lactobacillus species are best known for their lactic acid production used to produce cheese and other fermented foods (Briggiler-Marcó et al., 2007). Despite representing a minor proportion of the human gut microbiota (Nistal et al., 2016; Almonacid et al., 2017), increased or depleted Lactobacillus populations are associated with states of health and disease (Heeney et al., 2018; Zhang et al., 2018). More specifically, Lactobacillus species are reported to impart beneficial effects on the stress response and the immune system when used as a probiotic (Bravo et al., 2011; Palomar et al., 2014; Huang et al., 2016; Lew et al., 2019). Because of these health-promoting characteristics, they have become the focus of several gut microbiome studies in mammals (Zhang et al., 2018) which have paved the way for the potential use of Lactobacillus-based therapies to treat or prevent stress-induced psychological disorders (Huang et al., 2016; Lowry et al., 2016; Marin et al., 2017; Ng et al., 2018; Reis et al., 2018; Aizawa et al., 2019), such as depression and anxiety disorders that impact up to $8 \%$ of the world population (World Health Organization, 2017). 
A complex and bidirectional communication network exists between the gut and the central nervous system, which includes the enteric nervous system (ENS), the immune system and the modulation of neuroactive compounds by the microbiota (Grenham et al., 2011; Holzer and Farzi, 2014). Under stress, the microbiota is proposed to influence the central nervous system via the immune system and ENS (Foster and McVey Neufeld, 2013; Huang et al., 2016; Foster et al., 2017; Wallace and Milev, 2017). Indeed, Lactobacillus species are known to generate neuroactive and neuroimmune substances such as acetylcholine (Marquardt and Spitznagel, 1959; Stanaszek et al., 1977), nitric oxide (Sobko et al., 2006), histamine (Özogul et al., 2012; Thomas et al., 2012), as well as the neurotransmitters serotonin, dopamine (Özogul et al., 2012; Liu et al., 2016) and gamma-aminobutyric acid (GABA) (Yokoyama et al., 2002; Cho et al., 2007; Bravo et al., 2011). Therefore, Lactobacillus species may have the potential to prevent or aid in treatment of psychological disorders. To this end, a number of animal trials and recent reviews have investigated the impact of probiotic consumption on behavior related to psychological disorders.

Standardized behavioral tests, such as the forced swim test (FST), the sucrose preference test, or the tail suspension test, are routinely used in rodent models to assess the antidepressant potential of various compounds. For example, Bravo et al. (2011) demonstrated that ingesting Lactobacillus rhamnosus JB-1 reduces stress-induced immobility duration in the FST in adult male mice. The use of these animal models are largely pragmatic and they are not designed to fully represent psychological disorders (Gururajan et al., 2019; Reardon, 2019). Regardless, they can provide valuable information to understand the exact mechanisms through which Lactobacillus bacteria modulate gut-brain communication, as the exact role of the microbiota in psychological disorders remains poorly defined. To the best of our knowledge, no previous publication has systematically reviewed the effects of Lactobacillus-based supplementation on the behavioral outcomes of stressed vs. non-stressed rodent populations as measured by standard tests. Therefore, we hypothesize that, under experimental stressful conditions, rodents receiving a Lactobacillus-based supplement will demonstrate a shorter immobility duration measured in the FST compared to counterparts that receive a control supplement. A meta-analysis of published literature recording behavioral outcomes using the FST following a stress regimen in Lactobacillus-based supplement vs. control rodents were used to validate this hypothesis.

\section{MATERIALS AND METHODS}

\section{Search Strategy}

Protocols employed were based on the PRISMA guidelines. The goal of this analysis was to study the effect of Lactobacillus species supplementation and stress treatments on rodent behavior measured in standardized tests. ProQuest, ScienceDirect, Web of Science, and PubMed databases were systematically searched in January and February 2020. The search terms included: (Lactobacillus OR Lactobacilli OR Lactic acid bacteria) AND (stress OR stressful OR fear OR fearful OR psychological OR restraint OR social defeat NOT oxidative) AND (murine OR rodent $\mathrm{OR}$ rodents $\mathrm{OR}$ mouse $\mathrm{OR}$ mice $\mathrm{OR}$ rat OR rats) AND (mood disorder OR depression OR depressive OR anxiety OR stress behavior) in titles or abstracts without imposing time limitations. We also reviewed the references provided in each publication, as well as those provided in systematic review articles associated with mental health and stress-induced psychological or physical disorders.

Studies were deemed eligible if they met the following inclusion criteria:

- English language articles,

- Studies published in peer-reviewed journals with a randomized control group,

- Studies used mice or rats (not germ-free animals),

- Tested animals were directly supplemented with live Lactobacillus species (without any limitations on culture, strain, dose, or therapy regimen) as an experimental treatment (e.g., if the supplement was given to the mother of infant rodent, the study was excluded),

- A second experimental treatment included a stress directly administered to the individual or via a change in its environment. There were no limitations on category and numbers of stressors used, their frequency, duration and the order of the stressors compared to the Lactobacillus species supplementation,

- Following the supplementation and stress treatments, behavioral outcomes were measured in standardized tests commonly used in rodent models [i.e., the forced swim test (FST), the sucrose preference test, or tail suspension test]. These tests themselves can be considered as acute stressors for the animals (Commons et al., 2017). However, in this study, all animals underwent these standardized tests, regardless of whether they were in the experimental stressed group ("Stress") or not ("Non-stress") as described in criteria 5. As such, the standardized behavioral tests were considered separate from the experimental stress treatment

\section{Literature Search and Screening}

An adapted PRISMA flow diagram was used to represent the process of article and study selection for our meta-analysis (Figure 1). We did not use a pre-registered protocol for the systematic review and meta-analysis. In our initial search, 337 English language records, were identified which, after screening, revealed 171 unique articles. A total of 31 articles fulfilled the selection criteria using various standardized behavioral tests but the largest number of articles used the FST. The FST involves placing an animal in an inescapable container filled with water. The animal initially displays an active coping strategy, including behaviors such as climbing or swimming. This is followed by a passive coping strategy where they stay immobile and floating (Porsolt et al., 1977). For the current meta-analysis, we ultimately chose to focus on the articles measuring the immobility duration in the FST. This test is the most widely used screening tool in rodent models for the purpose of identifying novel antidepressant compounds (Cryan and Holmes, 2005; Kara et al., 2018). Furthermore, this strategy would allow collection 


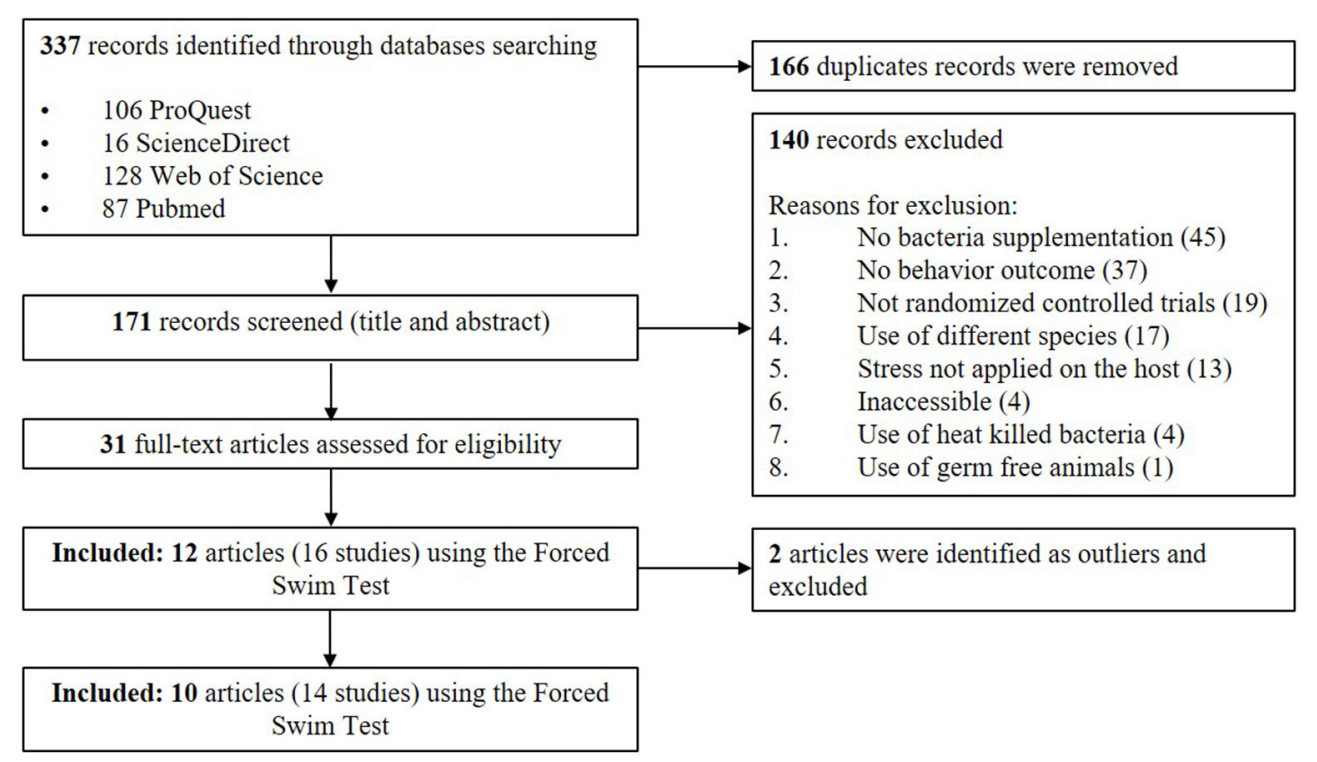

FIGURE 1 | PRISMA flow diagram of studies included in meta-analysis-Lactobacillus-based probiotics reduce the adverse effects of stress in rodents.

of a standardized outcome (immobility duration) needed to perform the meta-analysis (Kara et al., 2018). However, it should be acknowledged that the test is criticized for its cavalier use in depression research and its limitations are reviewed in the Discussion section (Molendijk and de Kloet, 2015; De Kloet and Molendijk, 2016; Reardon, 2019).

A total of 12 papers that fulfilled the selection criteria measuring the immobility duration in the FST after a Lactobacillus-based supplementation and a stress treatment were included in the quantitative meta-analysis. Stenman et al. (2020) and Jang et al. (2019) provided results from different 3 and 2 Lactobacillus-based probiotics supplementations, respectively; and Murray et al. (2019) used both males and females resulting in a total of 16 available studies for the meta-analysis. Characteristics of each study are shown in Table 1. Two articles were later excluded, as they contained individual points that were later (during statistical analysis) identified as outliers (Dhaliwal et al., 2018; Li et al., 2019). Thus, the final total number of studies retained in the final meta-analysis was 14 (Liu et al., 2016, 2019; Li et al., 2018; Morshedi et al., 2018; Jang et al., 2019; Liao et al., 2019; Murray et al., 2019; Sun et al., 2019; Wei et al., 2019; Stenman et al., 2020).

\section{Data Collection}

Data relating to the effect of Lactobacillus-based supplementation and stress treatment on the time spent immobile in the FST were extracted using a custom-tailored form (excel spreadsheet). The form included information on study populations (sex, age, breed, and body weight), trial designs, Lactobacillus supplementations (Lactobacillus species and strains, dosage, and duration), stress treatments (category of stressor, frequency, and duration) and behavioral outcomes (group sample sizes, mean value of effect and group variance). The durations of the Lactobacillus supplementation and the stress treatments were categorized as acute ( $\leq 7$ days) or chronic ( $>7$ days).

When results were available only in graphical format, data were extracted using GetData Graph Digitizer software (GetData Graph Digitizer., GetData Graph Digitizer.). Graph digitization has been previously shown to be a valid method for extracting study data (Guyot et al., 2012). Time spent immobile in the FST was reported either in seconds (s) or as a percentage of the total test time, with the variance expressed in standard error or standard deviation. To homogenize the dataset, all data were transformed into seconds and the uncertainty was expressed as standard error. If the data were unclear or some key data were missing, we attempted to contact the corresponding authors through email to obtain further information. All steps (manuscripts screening and data extraction) were performed by a single reviewer.

\section{Statistical Model Development}

All statistical analyses were completed using SAS ${ }^{\circledR}$ Studio University Edition. Preliminary calculations were completed in Microsoft ${ }^{\circledR}$ Excel $^{\circledR}$ 2016. Statistical significance was considered at $P<0.05$. Values are presented as least squares means (LSM) \pm standard error (SE), unless stated otherwise. A mixed model approach was utilized for this meta-analysis (generalized linear mixed model) in order to adequately model the random effect of study (St-Pierre, 2001).

The outcome of this study is the FST immobility time in seconds. Initially, we assessed the effect of Lactobacillusbased supplementation (Model 1: Supplemented, Control) and stress (Model 2: Stress, Non-stress) on the outcome separately. Following this, the main and final model was built including the effects of Lactobacillus-based supplementation, stress and their interaction (Model 3). Generalized linear mixed models (proc 
TABLE 1 | Characteristics of studies collected from the literature review search for the meta-analysis on the effect of Lactobacillus-based supplementation and stress treatments in rodents in the Forced Swim Test (FST).

\begin{tabular}{|c|c|c|c|c|c|c|c|}
\hline $\begin{array}{l}\text { References } \\
\text { (Study \#) }\end{array}$ & Subjects & $\begin{array}{l}\text { Bacterial species, } \\
\text { strain and dosage }\end{array}$ & $\begin{array}{l}\text { Probiotic } \\
\text { dose }\end{array}$ & $\begin{array}{l}\text { Stress } \\
\text { treatment }\end{array}$ & $\begin{array}{l}\text { Treatments } \\
\text { strategy }\end{array}$ & FST parameters & $\begin{array}{l}\text { Other } \\
\text { behavioral tests }\end{array}$ \\
\hline $\begin{array}{l}\text { Morshedi et al. (2018) } \\
\text { (1) }\end{array}$ & $\begin{array}{l}18 \text { Males Wistar } \\
\text { rats, 5-7 } \text { woa }^{d}\end{array}$ & $\begin{array}{l}\text { L. plantarum ATCC } \\
8014\left(10^{7} \mathrm{CFU} / \mathrm{ml}\right)\end{array}$ & $\begin{array}{l}1 \text { time/day for } \\
49 \text { days, via } \\
\text { gastric } \\
\text { gavage }\end{array}$ & $\begin{array}{l}\mathrm{STZ}^{\mathrm{a}}(35 \\
\mathrm{mg} / \mathrm{kg}) \text {, once, } \\
\text { via } \\
\text { intraperitoneal } \\
\text { injection }\end{array}$ & Reversal $\left.\right|^{f}$ & $\begin{array}{l}300 \mathrm{~s} \text { long, in Plexiglas } \\
\text { cylinder }(40 \mathrm{~cm} \text { depth, } \\
\varnothing \mathrm{i} 20 \mathrm{~cm}) \text { filled with } \\
\text { water at } 24 \pm 1{ }^{\circ} \mathrm{C} \\
24 \mathrm{~h} \text { earlier } \\
15 \text { min pretest }\end{array}$ & EPMi', FST \\
\hline $\begin{array}{l}\text { Murray et al. (2019) } \\
\text { (2) }\end{array}$ & $\begin{array}{l}40 \text { Males CD-1 } \\
\text { mice, } 3 \text { woa }\end{array}$ & $\begin{array}{l}\text { L. lactis, } L \text {. cremoris, } L \text {. } \\
\text { diacetylactis, } L \text {. } \\
\text { acidophilus }\left(3.0 \times 10^{9}\right. \\
\text { CFU/g) }\end{array}$ & $\begin{array}{l}3 \text { times/week } \\
\text { for } 21 \text { days, } \\
\text { via Kefir }\end{array}$ & $\begin{array}{l}\text { LPSb }(1.5 \\
\mathrm{mg} / \mathrm{kg}) \text {, once, } \\
\text { via } \\
\text { intraperitoneal } \\
\text { injection }\end{array}$ & Protection ${ }^{9}$ & $\begin{array}{l}300 \text { s long, } 4 \mathrm{~L} \text { glass } \\
\text { beaker filled with } 3 \mathrm{~L} \\
\text { water at } 24 \pm 2^{\circ} \mathrm{C} \\
\text { No pretest }\end{array}$ & $\begin{array}{l}\text { EPM, OFT', } \\
\text { Rotarod Test, FST }\end{array}$ \\
\hline $\begin{array}{l}\text { Murray et al. (2019) } \\
\text { (3) }\end{array}$ & $\begin{array}{l}40 \text { Females } \\
\text { CD-1 mice, } 3 \\
\text { woa }\end{array}$ & $\begin{array}{l}\text { L. lactis, } L \text {. cremoris, } L \text {. } \\
\text { diacetylactis, } L \text {. } \\
\text { acidophilus }\left(3.0 \times 10^{9}\right. \\
\text { CFU/g) }\end{array}$ & $\begin{array}{l}3 \text { times/week } \\
\text { for } 21 \text { days, } \\
\text { via Kefir }\end{array}$ & $\begin{array}{l}\text { LPS (1.5 } \\
\mathrm{mg} / \mathrm{kg}) \text {, once, } \\
\text { via } \\
\text { intraperitoneal } \\
\text { injection }\end{array}$ & Protection & $\begin{array}{l}300 \text { s long, in } 4 \mathrm{~L} \text { glass } \\
\text { beaker filled with } 3 \mathrm{~L} \\
\text { water at } 24 \pm 2^{\circ} \mathrm{C} \\
\text { No pretest }\end{array}$ & $\begin{array}{l}\text { EPM, OFT } \\
\text { Rotarod Test, FST }\end{array}$ \\
\hline Li et al. (2018) (4) & $\begin{array}{l}32 \text { Males } \\
\text { C57BL/6 } \\
\text { mice,6-8 woa }\end{array}$ & $\begin{array}{l}\text { L. helveticus R0052, L. } \\
\text { plantarum R1012, and } \\
\text { B. longum R0175 (10 × } \\
\left.10^{9} \mathrm{CFU} / \mathrm{mL}\right)\end{array}$ & $\begin{array}{l}1 \text { time/day for } \\
28 \text { days, via } \\
\text { oral gavage }\end{array}$ & $\begin{array}{l}\text { Chronic Mild } \\
\text { Stress, for } 28 \\
\text { days, at } \\
\text { variable } \\
\text { frequencies }\end{array}$ & Protection & $\begin{array}{l}240 \text { s long, in glass } \\
\text { cylinder }(23 \mathrm{~cm} \text { depth, } \varnothing \\
12 \mathrm{~cm}) \text { filled with water } \\
\text { at } 24 \pm 1^{\circ} \mathrm{C} \\
\text { No pretest }\end{array}$ & SPT', EPM, FST \\
\hline $\begin{array}{l}\text { Stenman et al. (2020) } \\
\text { (5) }\end{array}$ & $\begin{array}{l}47 \text { Males Swiss } \\
\text { mice, } 5 \text { woa }\end{array}$ & $\begin{array}{l}\text { L. paracasei Lpc- } 37, L \text {. } \\
\text { salivarius Ls-33 }(1 \times \\
10^{9} \mathrm{CFU} \text { per day) }\end{array}$ & $\begin{array}{l}1 \text { time/day for } \\
35 \text { days, via } \\
\text { oral gavage }\end{array}$ & $\begin{array}{l}\text { Chronic, for } \\
21 \text { days, } 1 \\
\text { time/day }\end{array}$ & Prevention ${ }^{h}$ & $\begin{array}{l}300 \mathrm{~s} \text { long, Water at } 22 \\
\pm 1^{\circ} \mathrm{C} \text { in transparent } \\
\text { cylinder }(24 \mathrm{~cm} \text { depth, } \varnothing \\
12 \mathrm{~cm}) \text { filled with } 12 \mathrm{~cm} \\
\text { water at } 22 \pm 1^{\circ} \mathrm{C} \\
\text { No pretest }\end{array}$ & $\begin{array}{l}\text { EPM, OFT, } \\
\text { NOR }^{m}, \text { FST }\end{array}$ \\
\hline $\begin{array}{l}\text { Stenman et al. (2020) } \\
\text { (6) }\end{array}$ & $\begin{array}{l}58 \text { Males Swiss } \\
\text { mice, } 5 \text { woa }\end{array}$ & $\begin{array}{l}\text { L. plantarum LP12418, } \\
\text { L. plantarum LP12151, } \\
\text { L. plantarum LP12407 } \\
\left(1 \times 10^{9} \mathrm{CFU} \text { per day }\right)\end{array}$ & $\begin{array}{l}1 \text { time/day for } \\
35 \text { days, via } \\
\text { oral gavage }\end{array}$ & $\begin{array}{l}\text { Chronic, for } \\
21 \text { days, } 1 \\
\text { time/day }\end{array}$ & Prevention & $\begin{array}{l}300 \mathrm{~s} \text { long, Water at } 22 \\
\pm 1^{\circ} \mathrm{C} \text { in transparent } \\
\text { cylinder }(24 \mathrm{~cm} \text { depth, } \varnothing \\
12 \mathrm{~cm}) \text { filled with } 12 \mathrm{~cm} \\
\text { water at } 22 \pm 1^{\circ} \mathrm{C} \\
\text { No pretest }\end{array}$ & $\begin{array}{l}\text { EPM, OFT, } \\
\text { NOR }^{m}, \text { FST }\end{array}$ \\
\hline $\begin{array}{l}\text { Stenman et al. (2020) } \\
\text { (7) }\end{array}$ & $\begin{array}{l}60 \text { Male Swiss } \\
\text { mice, } 5 \text { woa }\end{array}$ & $\begin{array}{l}\text { L. acidophilus LA11873, } \\
\text { L. rhamnosus LX11881 } \\
\text { (DGCC11881), L. } \\
\text { helveticus LH0138 (1 × } \\
10^{9} \text { CFU per day) }\end{array}$ & $\begin{array}{l}1 \text { time/day for } \\
35 \text { days, via } \\
\text { oral gavage }\end{array}$ & $\begin{array}{l}\text { Chronic, for } \\
21 \text { days, } 1 \\
\text { time/day }\end{array}$ & Prevention & $\begin{array}{l}300 \text { s long, in } \\
\text { transparent cylinder } \\
(24 \mathrm{~cm} \text { depth, } \varnothing 12 \mathrm{~cm}) \\
\text { filled with } 12 \mathrm{~cm} \text { water at } \\
22 \pm 1^{\circ} \mathrm{C} \\
\text { No pretest }\end{array}$ & $\begin{array}{l}\text { EPM, OFT, } \\
\text { NOR }^{m}, \text { FST }\end{array}$ \\
\hline
\end{tabular}


TABLE 1 | Continued

\begin{tabular}{|c|c|c|c|c|c|c|c|}
\hline $\begin{array}{l}\text { References } \\
\text { (Study \#) }\end{array}$ & Subjects & $\begin{array}{l}\text { Bacterial species, } \\
\text { strain and dosage }\end{array}$ & $\begin{array}{l}\text { Probiotic } \\
\text { dose }\end{array}$ & $\begin{array}{l}\text { Stress } \\
\text { treatment }\end{array}$ & $\begin{array}{l}\text { Treatments } \\
\text { strategy }\end{array}$ & FST parameters & $\begin{array}{l}\text { Other } \\
\text { behavioral tests }\end{array}$ \\
\hline Jang et al. (2019) (8) & $\begin{array}{l}28 \text { Male } \\
\text { C57BL/6 mice, } \\
5 \text { woa }\end{array}$ & $\begin{array}{l}\text { L. reuteri NK33 }\left(1 \times 10^{9}\right. \\
\text { CFU per day) }\end{array}$ & $\begin{array}{l}1 \text { time/day for } \\
5 \text { days, via } \\
\text { oral gavage }\end{array}$ & $\begin{array}{l}\text { Immobilization, } \\
\text { for } 2 \text { days, } 1 \\
\text { time/day }\end{array}$ & Reversal & $\begin{array}{l}300 \text { s long, in } \\
\text { transparent plastic jar } \\
(40 \mathrm{~cm} \text { depth) filled with } \\
25 \mathrm{~cm} \text { water at } 25^{\circ} \mathrm{C} \\
\text { No pretest }\end{array}$ & $\begin{array}{l}\text { EPM, LDTn, } \\
\text { TSTo }^{\circ} \text {, FST }\end{array}$ \\
\hline Jang et al. (2019) (9) & $\begin{array}{l}28 \text { Males } \\
\text { C57Bᄂ/6 mice, } \\
5 \text { woa }\end{array}$ & $\begin{array}{l}\text { L. reuteri NK33 and } B \text {. } \\
\text { adolescentis NK98 }(1 \times \\
10^{9} \mathrm{CFU} \text { per day) }\end{array}$ & $\begin{array}{l}1 \text { time/day for } \\
5 \text { days, via } \\
\text { oral gavage }\end{array}$ & $\begin{array}{l}\text { Immobilization, } \\
\text { once }\end{array}$ & Prevention & $\begin{array}{l}300 \text { s long, in } \\
\text { transparent plastic jar } \\
(40 \mathrm{~cm} \text { depth) filled with } \\
25 \mathrm{~cm} \text { water at } 25^{\circ} \mathrm{C} \\
\text { No pretest }\end{array}$ & $\begin{array}{l}\text { EPM, LDT } \\
\text { TST }^{\circ}, \text { FST }\end{array}$ \\
\hline Liu et al. (2019) (10) & $\begin{array}{l}18 \text { Males Wistar } \\
\text { rats, } 7-8 \text { woa }\end{array}$ & $\begin{array}{l}\text { L. fermentum PS150 ( } 1 \\
\times 10^{9} \mathrm{CFU} \text { per day) }\end{array}$ & $\begin{array}{l}1 \text { time/day for } \\
28 \text { days, via } \\
\text { oral gavage }\end{array}$ & $\begin{array}{l}\text { Chronic Mild } \\
\text { Stress, for } 28 \\
\text { days, } 3 \\
\text { times/day }\end{array}$ & Protection & $\begin{array}{l}300 \mathrm{~s} \text { long, Water at } 23 \\
\pm 1^{\circ} \mathrm{C} \text { in transparent } \\
\text { glass container }(50 \mathrm{~cm} \\
\text { depth and } \varnothing 20 \mathrm{~cm}) \\
24 \mathrm{~h} \text { earlier } \\
15 \text { min pretest }\end{array}$ & 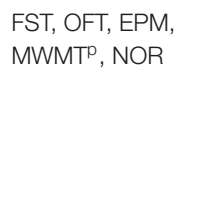 \\
\hline Liu et al. (2016) (11) & $\begin{array}{l}32 \text { Males } \\
\text { C57BL/6J mice, } \\
2 \text { doa }^{\mathrm{e}}\end{array}$ & $\begin{array}{l}\text { L. plantarum PS128 }(1 \\
\times 10^{9} \mathrm{CFU} \text { per day) }\end{array}$ & $\begin{array}{l}1 \text { time/day for } \\
28 \text { days, via } \\
\text { oral gavage }\end{array}$ & $\begin{array}{l}\text { Maternal } \\
\text { separation, } \\
\text { for } 12 \text { days, } 1 \\
\text { time/day }\end{array}$ & Reversal & $\begin{array}{l}300 \text { s long, in } \\
\text { transparent acrylic } \\
\text { cylinder }(30 \mathrm{~cm} \text { depth } \\
\text { and } \varnothing 20 \mathrm{~cm}) \text { filled with } \\
15 \mathrm{~cm} \text { water at } 24 \pm \\
1^{\circ} \mathrm{C} \\
\text { No pretest }\end{array}$ & $\begin{array}{l}\text { SPT, OFT,EPM, } \\
\text { FST }\end{array}$ \\
\hline Liao et al. (2019) (12) & $\begin{array}{l}20 \text { Males } \\
\text { C57BL/6J mice, } \\
2 \text { doa }\end{array}$ & $\begin{array}{l}\text { L. paracasei PS23 }(1 \times \\
\left.10^{9} \mathrm{CFU} \text { per day }\right)\end{array}$ & $\begin{array}{l}1 \text { time/day for } \\
28 \text { days, via } \\
\text { oral gavage }\end{array}$ & $\begin{array}{l}\text { Maternal } \\
\text { separation, } \\
\text { for } 12 \text { days, } 1 \\
\text { time/day }\end{array}$ & Reversal & $\begin{array}{l}360 \text { s long, in } \\
\text { transparent acrylic } \\
\text { cylinder }(30 \mathrm{~cm} \text { depth } \\
\text { and } \varnothing 10 \mathrm{~cm}) \text { filled with } \\
15 \mathrm{~cm} \text { water at } 24 \pm \\
1^{\circ} \mathrm{C} \\
24 \mathrm{~h} \text { earlier } 6 \mathrm{~min} \text { pretest }\end{array}$ & OFT, EPM, FST \\
\hline Wei et al. (2019) (13) & $\begin{array}{l}24 \text { Males } \\
\text { C57BL/6J mice, } \\
\text { 6-8 woa }\end{array}$ & $\begin{array}{l}\text { L. paracasei PS23 }(5 \times \\
\left.10^{8} \mathrm{cells} / \mathrm{ml}\right)\end{array}$ & $\begin{array}{l}1 \text { time/day for } \\
40 \text { days, via } \\
\text { oral gavage }\end{array}$ & $\begin{array}{l}\text { Cort }(40 \\
\mathrm{mg} / \mathrm{kg} \text { ), for } 20 \\
\text { days, } 1 \\
\text { time/day, via } \\
\text { subcutaneous } \\
\text { injection }\end{array}$ & Prevention & $\begin{array}{l}360 \mathrm{~s} \text { long, in acrylic } \\
\text { cylinder }(25 \mathrm{~cm} \text { depth } \\
\text { and } \varnothing 9 \mathrm{~cm}) \text { filled with } \\
15 \mathrm{~cm} \text { water at } 24-25^{\circ} \mathrm{C} \\
48 \mathrm{~h} \text { earlier } \\
6.5 \text { min pretest }\end{array}$ & OFT, FST, SPT \\
\hline
\end{tabular}


TABLE 1 | Continued

\begin{tabular}{|c|c|c|c|c|c|c|c|}
\hline $\begin{array}{l}\text { References } \\
\text { (Study \#) }\end{array}$ & Subjects & $\begin{array}{l}\text { Bacterial species, } \\
\text { strain and dosage }\end{array}$ & $\begin{array}{l}\text { Probiotic } \\
\text { dose }\end{array}$ & $\begin{array}{l}\text { Stress } \\
\text { treatment }\end{array}$ & $\begin{array}{l}\text { Treatments } \\
\text { strategy }\end{array}$ & FST parameters & $\begin{array}{l}\text { Other } \\
\text { behavioral tests }\end{array}$ \\
\hline Sun et al. (2019) (14) & $\begin{array}{l}24 \text { Males } \\
\text { Kunming mice, } \\
\text { adult }\end{array}$ & $\begin{array}{l}\text { L. kefiranofaciens ZW3 } \\
\left(1 \times 10^{9} \mathrm{CFU} \text { per day }\right)\end{array}$ & $\begin{array}{l}1 \text { time/day for } \\
7 \text { days, via } \\
\text { oral gavage }\end{array}$ & $\begin{array}{l}\text { Chronic } \\
\text { Unpredictable } \\
\text { Mild Stress, } \\
\text { for } 42 \text { days, } 1 \\
\text { time/day }\end{array}$ & Reversal & $\begin{array}{l}240 \text { s long, in } \\
\text { transparent beaker } \varnothing \\
16 \mathrm{~cm}) \text { filled with } 10 \mathrm{~cm} \\
\text { water at } 25^{\circ} \mathrm{C} \\
24 \mathrm{~h} \text { earlier } \\
15 \text { min pretest }\end{array}$ & SPT, OFT, FST \\
\hline Li et al. (2019)c (15) & $\begin{array}{l}30 \text { Males Wistar } \\
\text { mice, adult }\end{array}$ & $\begin{array}{l}\text { L. rhamnosus }\left(1 \times 10^{9}\right. \\
\text { CFU/100 g weight })\end{array}$ & $\begin{array}{l}1 \text { time/day for } \\
28 \text { days, via } \\
\text { oral gavage }\end{array}$ & $\begin{array}{l}\text { Chronic } \\
\text { Unpredictable } \\
\text { Mild Stress, } \\
\text { for } 28 \text { days, } 1 \\
\text { time/day }\end{array}$ & Protection & $\begin{array}{l}300 \mathrm{~s} \text { long in Perspex } \\
\text { cylinder filled with } 30 \mathrm{~cm} \\
\text { water at } 25^{\circ} \mathrm{C} \\
24 \mathrm{~h} \text { earlier } \\
15 \text { min pretest }\end{array}$ & FST, SPT \\
\hline $\begin{array}{l}\text { Dhaliwal et al. (2018) } \\
\text { (16) }\end{array}$ & $\begin{array}{l}48 \text { Males Swiss } \\
\text { albino LACA } \\
\text { mice, adult }\end{array}$ & $\begin{array}{l}\text { L. plantarum MTCC } \\
9510\left(2 \times 10^{10} \mathrm{CFU}\right)\end{array}$ & $\begin{array}{l}1 \text { time/day for } \\
28 \text { days, via } \\
\text { oral gavage }\end{array}$ & $\begin{array}{l}\text { Chronic } \\
\text { Unpredictable } \\
\text { Mild Stress, } \\
\text { for } 28 \text { days, } 1 \\
\text { time/week }\end{array}$ & Protection & $\begin{array}{l}360 \text { s long in rectangular } \\
\text { glass jar }(25 \times 12 \times 25 \\
\left.\mathrm{cm}^{3}\right) \text { filled with } 15 \mathrm{~cm} \\
\text { water at } 24 \pm 1^{\circ} \mathrm{C} \\
\text { No pretest }\end{array}$ & $\begin{array}{l}\text { FST, TST EZM } \\
\text { MCT' }^{r}, \text { MWMT, } \\
\text { PAT }^{s}\end{array}$ \\
\hline
\end{tabular}

a Streptozotocin.

${ }^{b}$ Lipopolysaccharide.

c/dentified as an outlier and removed from the meta analysis.

${ }^{d}$ Week of age at the beginning of the trial.

${ }^{e}$ Day of age at the beginning of the trial.

${ }^{f}$ Reversal: The Lactobacillus-based supplementation was applied after the stress treatment.

gProtection: The Lactobacillus-based supplementation was during before the stress treatment.

hPrevention: The Lactobacillus-based supplementation was applied before the stress treatment.

¿Ø represent the diameter.

${ }^{j}$ Elevated Plus Maze.

kOpen Field Test.

'Sucrose Preference Test.

${ }^{m}$ Novel Object Recognition

"nLight Dark Transition Task

- Tail Suspension Test.

PMorris Water Maze Test.

${ }^{a}$ Elevate Zero Maze.

'Mirror Chamber Test.

${ }^{s}$ Passive avoidance Test. 
glimmix) were used with the study included as a random effect. The following additional variables were added to the main model (Model 3) as covariates to assess their impact on the outcome: the study design (number of additional behavioral tests used, presence of a pretest, container's diameter and depth, water depth and temperature), the population (species, breed, sex and age), differences in the Lactobacillus-based supplementation treatment (number of strains used, concentration, duration, frequency and method of the supplementation), and differences in the stress treatment (category, duration, frequency) and whether the stressor was applied before (prevention), during (protection) or after (reversal) the supplementation (Table 1).

\section{Statistical Model Evaluation}

The requirement for normally distributed and homogeneous studentized conditional residuals/random effect of study were examined graphically with the use of residual, histogram, and QQ plots. The covariance structure was chosen according to the goodness-of-fit statistics [Akaike information criterion (AIC) and Bayesian information criterion (BIC)]. Differences between LSMs were compared pairwise using a Tukey-Kramer adjustment for multiple comparisons. To detect possible study outliers, the Cook's distance was used with a $4 / n$ cut-off, where $\mathrm{n}$ is the number of studies (Kutner et al., 2005). The mean difference $\left(\mathrm{MD}, \mathrm{MD}_{\text {stress }}=\right.$ Mean $_{\text {stress }}-\mathrm{Mean}_{\text {non-stress; }}$; $\mathrm{MD}_{\text {supplementation }}=$ Mean $_{\text {Lactobacillus }}-$ Mean $_{\text {control }}$ ) and standard error of the difference (SED) were calculated to assess biases via funnel plots (Higgins and Thomas, 2019) and response heterogeneity using forest plots. When two or more Lactobacillus-based supplementation treatment groups were involved in one study (for example, with differing strain or dose), the data of the different groups were averaged as one group for funnel/forest plot analysis. Since the outcomes of recruited studies were continuous data, the $95 \%$ confidence intervals (CI) were calculated for statistical analyses and plotting. In the funnel/forest plots representing the effect of the stress and Lactobacillus-based supplementation treatment, a $\mathrm{MD}>$ 0 indicates that the stress treatment or Lactobacillus-based supplementation increased the FST immobility time. On the contrary, a $\mathrm{MD}<0$ indicated that the stress treatment and the Lactobacillus-based supplementation decreased the length of immobility in the FST.

To evaluate the model's goodness-of-fit, scatter plots of residuals vs. adjusted (for the random effect of study) predicted values and predicted vs. observed values were plotted. The significance of the slope and intercept of the residual vs. adjusted predicted plots and interfering factors (covariates), were tested against zero and the slope/intercept of the predicted vs. observed plots against $1 / 0$. These were evaluated in proc reg (SAS).

The impact of the Lactobacillus-based supplementation and stress treatment on the FST immobility time prediction equation(s) were evaluated using two methods.

Firstly, the mean square prediction error (MSPE) was calculated as

$$
\text { MPSE }=\sum_{i=1}^{n}(O i-P i)^{2} / n
$$

where $n$ is the total number of observations, $O_{i}$ is the observed value, and $P_{i}$ is the predicted value. The root mean square prediction error (rMSPE) was expressed as a percentage of the observed mean to give an estimate of the overall prediction error.

The rMSPE was then further decomposed into error due to overall bias (ECT), error due to deviation of the regression slope from unity (ER) and error due to the disturbance (random error) (ED) (Bibby and Toutenburg, 1977). The ECT, ER and ED fractions of MSPE were calculated as:

$$
\begin{gathered}
E C T=(P-O)^{2}, \\
E R=\left(S_{p}-R^{*} S_{o}\right)^{2}, \\
E D=\left(1-R^{2}\right)^{*} S_{o}^{2},
\end{gathered}
$$

where $P$ and $O$ are the predicted and observed means, respectively, $S p$ is the predicted standard deviation, $S_{o}$ is the observed standard deviation and $R$ is the Pearson correlation coefficient. The ECT, ER and ED were then expressed as a percentage of the MPSE and sum to account for $100 \%$ of the error.

Secondly, concordance correlation coefficient analysis (CCC) was performed (Lin, 1989), where CCC was calculated as:

$$
C C C=R^{*} C_{b}
$$

where $R$ is the Pearson correlation coefficient and $C_{b}$ is a bias correction factor, the latter was calculated as:

$$
C b=\frac{2}{\left(V+\frac{1}{V}+u^{2}\right)},
$$

where

$$
V=\frac{S o}{S p}
$$

and

$$
\mathrm{u}=\frac{O-P}{\left(S o^{*} S p\right)^{1 / 2}}
$$

\section{RESULTS}

\section{Preliminary Assessment of the Data}

Funnel plots (Figures 2A,B) were used to visually assess the dataset for publication bias. Such plots presume that data should exist within a 95\% confidence funnel, whereby highly precise studies with a low standard error of the difference (SED) should exist close to the average/true effect size (vertical line) and that as SED increases so will the scatter of those points around the average/true effect size. Each point within a funnel plot represents a study's mean difference (MD).

Both funnel plots are partially symmetrical, indicating no obvious evidence of asymmetry, and, therefore, no evidence of publication bias. Both funnel plots show that all studies were comparatively precise. One study (Wei et al., 2019, Study 13) was found to have a higher SED relative to all others in this analysis. This was due to a much higher SE in all their treatments groups. 


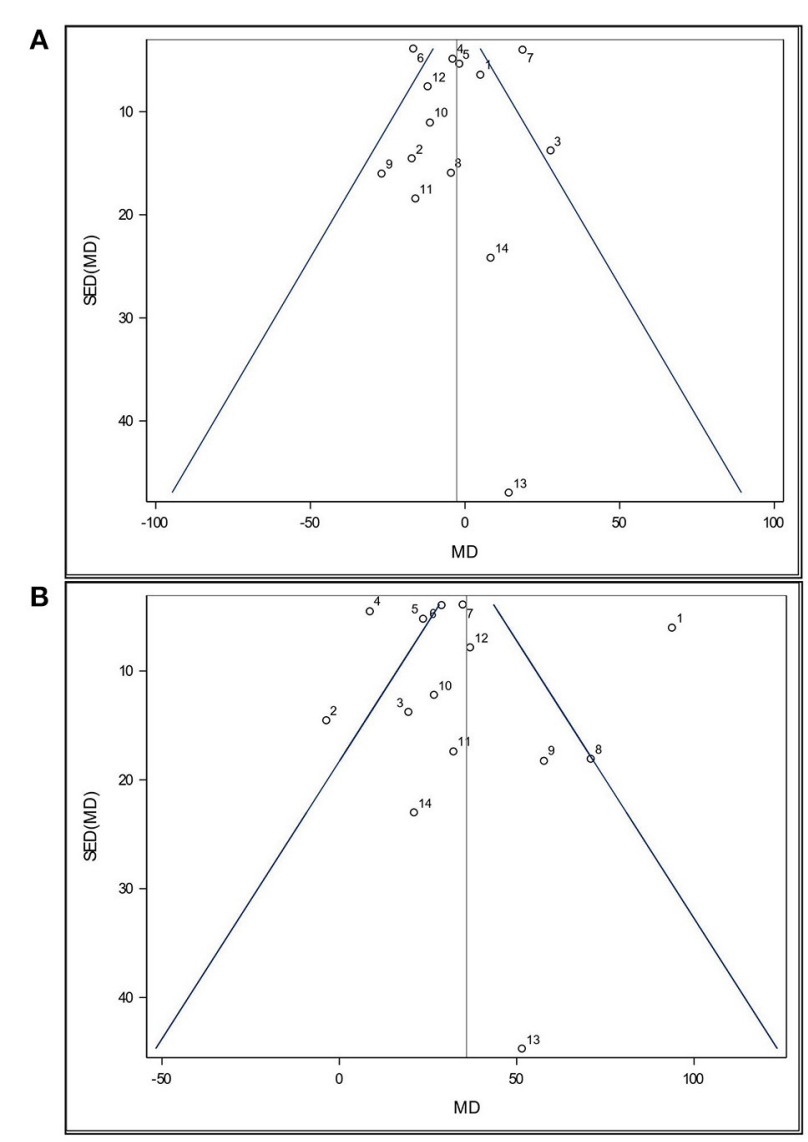

FIGURE 2 | Funnel plot of the effects of (A) Lactobacillus-based probiotic supplementation and (B) stress on time spent immobile (s) in the Forced Swim Test in rodents for all included studies $(n=14)$. Dots represent mean difference (MD, Lactobacillus-based probiotic - Control; stress - non stress) and standard error of the mean difference [SE(MD)] for each study, blue lines represent $95 \% \mathrm{Cl}$, and the black line represents the overall fixed effect average.

While study 13 appeared less precise, the MD value is still close to the overall effect size (Figures 2A,B). Since this study was not reported as an outlier by Cook's distance, it was retained in the analysis. Additionally, three studies showed a small SE compared to their large stress effect size (Study 1, 2, and 4). However, no distinction in experimental design was found.

As a preliminary analysis and visualization of the dataset, Figures 3A,B present a forest plot of the stress and probiotic effect sizes (mean difference, MD: stress - non-stress; Lactobacillus-based supplementation - Control) by study with $95 \%$ confidence intervals. In Figure $\mathbf{3 A}$, this preliminary visual assessment shows that the average $\mathrm{MD}_{\text {stress }}$ of the FST immobility time was positive, indicating that stressed animals had a higher average immobility time in the FST. In Figure 3B, visual assessment shows that the average $\mathrm{MD}_{\text {supplementation }}$ of the immobility time in the FST was slightly below 0 , indicating that the animals receiving the Lactobacillus-based supplementation treatment decreased the time spent immobile in the FST compared to those receiving the control supplement. Such plots and averages represent the fixed effect analysis of Model 1 and Model 2 and a high-level visual examination of the data.

\section{Meta-Analysis Model Predictions}

The results of the three models developed (supplementation alone, stress alone, supplementation $\times$ stress) across studies are presented in Table 2. Model 1 shows no effect of the Lactobacillus-based supplementation on time spent immobile in the FST [Model 1, $(95 \% \mathrm{CI})-9.75$ to $15.52, \mathrm{~F}_{1,35}=0.21$; $P=0.647]$. Model 2 shows a significant effect of the stress treatment [Model 2, (95\% CI) -33.68 to $-11.09, \mathrm{~F}_{1,37}=16.13$; $P<0.001]$, whereby stress treatment significantly increased the duration of immobility in rodents within the FST. Model 3 shows a significant interaction of supplementation and stress treatments (Model 3, $\mathrm{F}_{1,35}=14.68 ; P<0.001$ ). Supplementation with Lactobacillus-based probiotics mitigated the immobility duration in stressed rodents [Supplemented-Stress: $130.0 \pm$ 17.82 s vs. Control-Stress: $152.7 \pm 17.94$ s, (95\% CI) $12.23-$ 33.07, $P<0.001$ ]. However, Lactobacillus-based probiotics did not significantly impact immobility duration in the nonstressed populations [Supplemented-Non-Stress: $135.9 \pm 19.89 \mathrm{~s}$ vs. Control-Non-Stress: $114.30 \pm 17.94 \mathrm{~s},(95 \% \mathrm{CI})-42.33$ to $-0.87, P=0.168]$. Based on the above results, we conclude that across 14 studies, Lactobacillus-based supplementation alone did not impact the duration of immobility in the FST (Model 1) while a stress treatment alone increased the duration of immobility (Model 2). Our main model (Model 3) showed similar results but, more importantly, it highlighted that the Lactobacillusbased supplementation reduced the duration of immobility in the FST in the stressed rodent population compared to the control stressed population. The Lactobacillus-based supplement had no effect on the non-stressed populations.

\section{Potential Impact of Covariates on the Duration of Immobility}

Variables related to the study design (presence of a pretest, container's diameter and depth, water depth and temperature), the rodent population (species, breed, sex and age), the stress treatment (duration, frequency, category, order of administration relative to the supplement), and the Lactobacillusbased supplementation (specific bacterial strain, supplement duration and bacterial dosage) were tested as potential sources of variation in predicting immobility time in the FST. The tested variables were not significant when added to Model 3 as covariates $(P>0.05)$. These variables were not kept in Model 3 , but to further illustrate their impact, the (marginal) residuals of Model 3 were plotted against these covariates (population species, sex and age; stress treatment duration, category and order; Lactobacillus-based supplementation duration, dosage and strains) (Figures 4-6).

There is a clear and unequal distribution of sex (Figure 4A) and species (Figure 4B) of the rodents across our data. Indeed, only one study in our meta-analysis utilized females (Murray et al., 2019) and only two studies assessed rats (Morshedi et al., 2018; Liu et al., 2019). The female study showed a tendency to over-predict the immobility duration in the FST (Figure 4A). The residuals were balanced in studies using 
A

Paper

Sun et al., 2019

Wei et d., 2019

Liao et d., 2019

Liu et al., 2016

Liu et al., 2019

Jang et d., 2019

Jang et d., 2019

2020 Group 3

Stenman ed d., 2020 Group 2

Stenman et d., 2020 Group 1

Li et d., 2018

Murray et al., 2019 Group 2

Murray ed d., 2019 Group 1

Morshedi et al., 2018$$
-100
$$

B

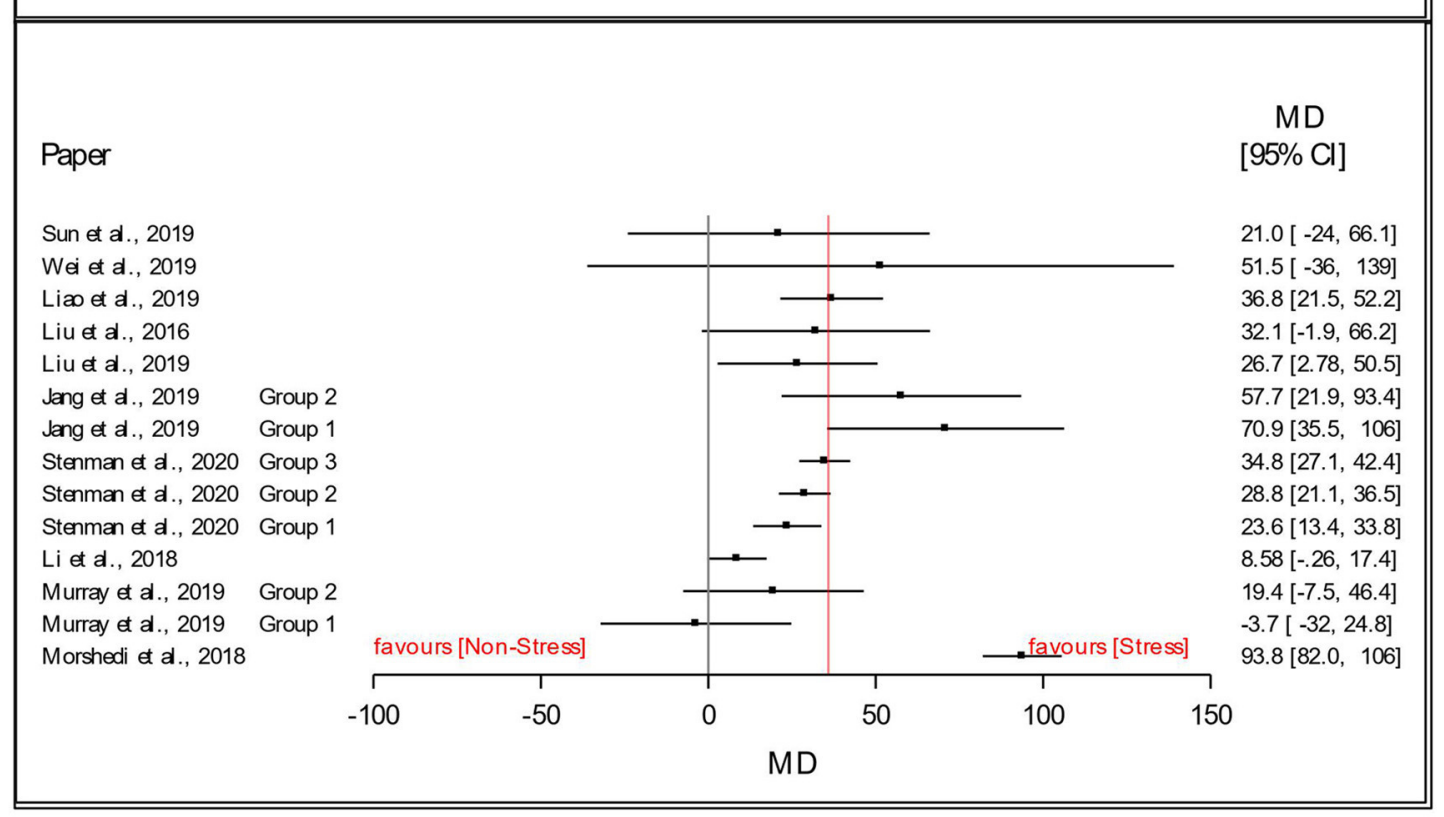

FIGURE 3 | Data and forest plot of the effect of (A) Lactobacillus-based probiotic supplementation and (B) stress on time spent immobile (s) in the Forced Swim Test in rodents for all included studies $(n=14)$. Dots represent mean difference (MD, Lactobacillus-based probiotic-Control; stress-non stress) for each study, lines represent $95 \% \mathrm{Cl}$, and the red line represents the overall fixed effect average.

rats and mice (Figure 4B). In contrast, data were distributed equally across age (adult vs. juvenile), and residuals in adults (10 studies) and in juveniles (four studies) appear balanced (Figure 4C).

The duration of the stress treatment showed balanced residuals across both acute and chronic stressors (Figure 5A). Three main categories of stress (injection of a substance, environmental stress and social stress) were used in the 14 studies of this meta-analysis. While predictions are balanced for the substance injections and environmental stress, the two studies using maternal separation as a social stressor underpredicted immobility duration (Figure 5B). Residuals were balanced regardless of the order in which studies supplemented or stressed their population (Figure 5C).

The duration of the Lactobacillus-based supplementation is also unequally distributed across our data. Indeed, only three studies (Jang et al., 2019; Sun et al., 2019) administered supplements short-term, which resulted in over-predicting the immobility duration in the FST (Figure 6A). The probiotic dose within the studies used in the meta-analysis ranged between $1 \times$ 
TABLE 2 | Predictive equation of the immobility duration [in seconds (Y)] spend in the Forced Swim Test (FST) based on the Lactobacillus-based supplementation and stress treatments in rodents.

\begin{tabular}{|c|c|c|c|}
\hline Model & Fixed effect & Equation: estimate $(\mathbf{s}) \pm$ standard error & $P$-value \\
\hline \multirow[t]{2}{*}{ Model 1: Supplementation } & Control $(n=28)$ & $Y=133.47 \pm 17.7913 a$ & 0.6469 \\
\hline & Supplemented ( $n=24)$ & $Y=130.59 \pm 17.9145 a$ & \\
\hline \multirow[t]{2}{*}{ Model 2: Stress } & Non-Stress $(n=17)$ & $Y=117.28 \pm 18.0394 a$ & 0.0003 \\
\hline & Stress $(n=35)$ & $Y=139.66 \pm 17.7479 b$ & \\
\hline \multirow[t]{4}{*}{ Model 3: Supplementation * Stress } & Control Non-Stress $(n=14)$ & $Y=114.30 \pm 17.9364 b$ & 0.0005 \\
\hline & Control Stress $(n=14)$ & $Y=152.65 \pm 17.9364 a$ & \\
\hline & Supplemented Non-Stress $(n=3)$ & $Y=135.90 \pm 19.8877 \mathrm{ab}$ & \\
\hline & Supplemented Stress $(n=21)$ & $Y=130.00 \pm 17.8201 b$ & \\
\hline
\end{tabular}

Different letters indicate statistically significant differences within the same Model $(P<0.05)$.

$10^{7}$ and $2 \times 10^{10}$ colony forming units (CFU) (Figure 6B). Only one study (Dhaliwal et al., 2018) supplied a $2 \times 10^{10} \mathrm{CFU}$ dose, which under predicted the duration of immobility in the FST (Figure 6B). Our analysis consisted of seven studies using a single bacterial strain, while the remaining seven used a combination of two to four strains, and no more than three studies used the same strain. However, the predictions for the studies using the same strains (L. paracasei and L. plantarum) and studies using combinations of strains are balanced (Figure 6C).

The number of other additional behavioral tests (e.g., sucrose preference test or tail suspension test, Table 1) used for each of the 14 studies was also tested as a covariate in the Model 3 and was found to significantly impact the immobility duration in the FST $(P=0.0188)$ without changing the overall impact of the supplementation or stress. To further interpret this impact, we incremented Model 3 separately (deemed Model 4; not reported) to assess the interaction between the number of other behavioral tests and the Lactobacillus-based supplement, as well as the interaction between the number of other behavioral tests and the stress treatment on the outcome.

We report that, while the interaction between the number of other behavioral tests and the Lactobacillusbased supplementation was not significant $(P=0.2469)$, the interaction between the number of other additional behavioral tests and the stress treatment was significant in determining the immobility duration in the FST $(P=0.0309)$. The addition of this variable to the model did not change the overall impact of the supplementation or stress treatment compared to Model 3. Furthermore, there was a low number of observations $(n=1)$ in the treatment groups, and the order in which the other tests were administered were not always specified. Thus, the variable was not retained, and Model 3 was selected as the final model.

\section{Model Evaluation}

The predicted vs. observed and predicted vs. residual plots of Model 3 are presented in Figures 7, 8, respectively. The predicted values are conditional and adjusted for the random effect of study. Results show good agreement between predictions and observations, indicating that the model described the betweenand within- study variation well. Assessment of the residual vs. adjusted predicted values showed no slope or mean bias $(P>$ 0.05) (Figure 7).

Evaluation of Model 3 predictions via rMSPE and CCC analysis (Table 3) shows good statistical agreement between predictions and observations, which were typically both very precise $(\mathrm{R})$ and accurate $\left(\mathrm{C}_{\mathrm{b}}\right)$, with a CCC value of 0.981 and an rMSPE value of $9.293 \%$ (Table 3).

\section{DISCUSSION}

This study systematically reviewed and performed a metaanalysis of published randomized control trials (RCTs) assessing the effect of Lactobacillus-based probiotics and stress treatments on the duration of immobility in the Forced Swim Test (FST) in rodents. We conclude that Lactobacillus-based probiotics significantly reduced immobility in stressed rodents by $15 \%$ relative to a control treatment in the context of the FST. Previously published studies have suggested that ingesting specific strains of Lactobacillus species decreases anxiety- and depression-related behavior (Bravo et al., 2011; Mackos et al., 2013; Ohland et al., 2013) and provides a protective effect during stress (Gareau et al., 2007; Mackos et al., 2013, 2016). Our findings are also consistent with previous meta-analyses, which demonstrate compelling, alleviating effects of probiotics on human psychological disorders (Huang et al., 2016; McKean et al., 2017; Wallace and Milev, 2017). Consequently, it is tempting to postulate that bacteria belonging to the Lactobacillus genus may help to alter some behavioral traits manifested in psychological disorders.

Depression is a multifactorial disorder in humans. Its core symptoms include a depressed mood, a feeling of worthlessness, and recurring thoughts of death or suicide which are impossible to model in laboratory animals. The original version of the FST was designed to be "a primary screening test for antidepressants" (Porsolt et al., 1977). A drug's ability to reduce passive coping (i.e., decrease the duration of immobility) in the FST was found to be a predictor of its efficacy as an antidepressant in humans (Petit-Demouliere et al., 2005; Castagné et al., 2011). However, the FST's successful predictive validity for antidepressants has led to the anthropomorphic over-interpretation of its outcomes, whereby increased immobility is equated to behavioral despair 


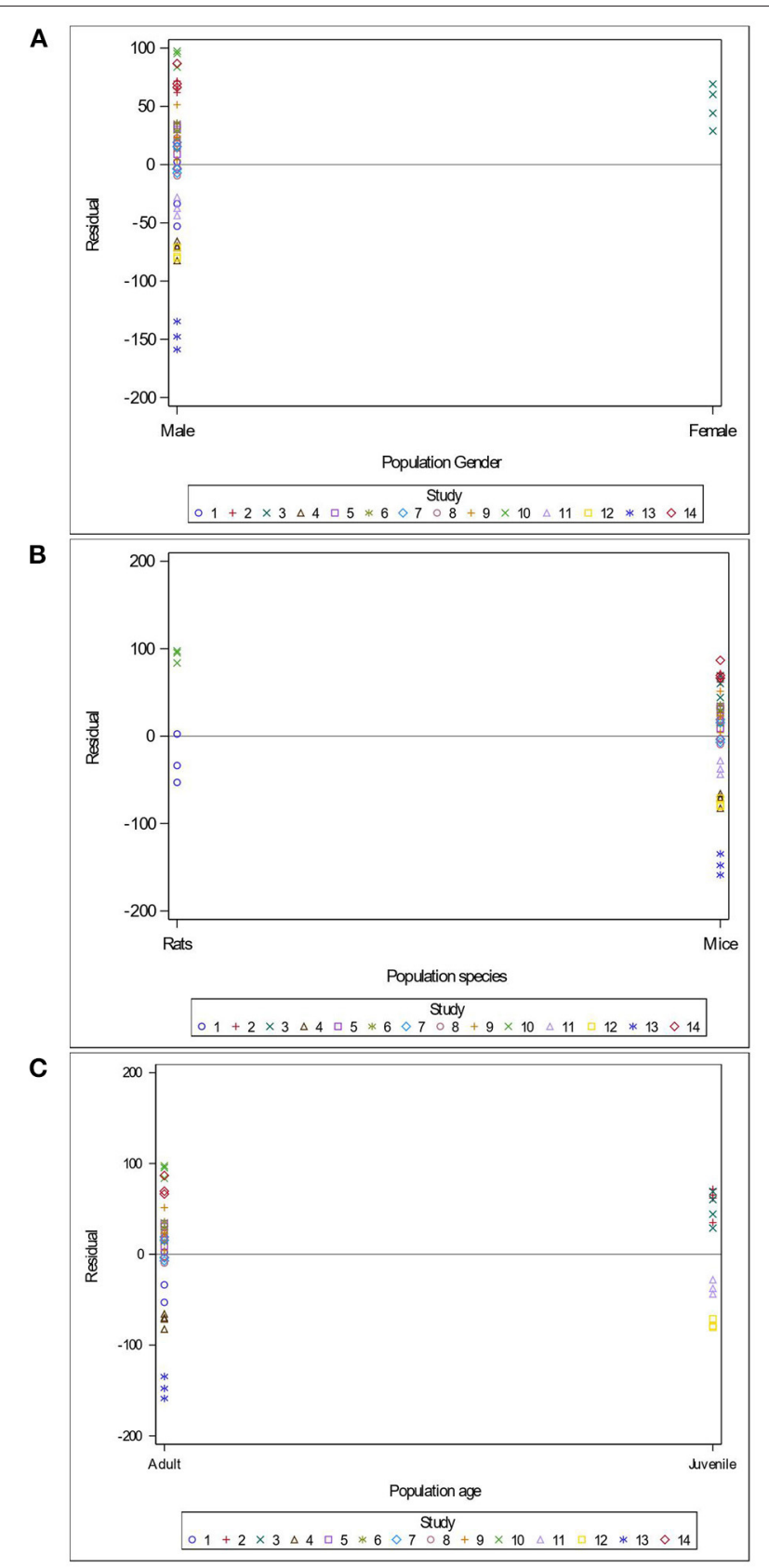

FIGURE 4 | Raw residuals of Model 3 (Supplementation*Stress) plotted against the sex $(\mathbf{A})$, species $(\mathbf{B})$ and age $(\mathbf{C})$ of the population, where points represent treatment means and are coded by study. or "depressive-like" traits (Molendijk and de Kloet, 2015; Yankelevitch-Yahav et al., 2015; De Kloet and Molendijk, 2016).

Therefore, while our results suggest that Lactobacillus bacteria may be effective in alleviating some depression symptoms, it should be noted that the FST is not analogous to the disorder in its entirety (Commons et al., 2017). Indeed, each standardized test (e.g., FST, tail suspension tests, sucrose preference) aimed at measuring various aspects of depression
A

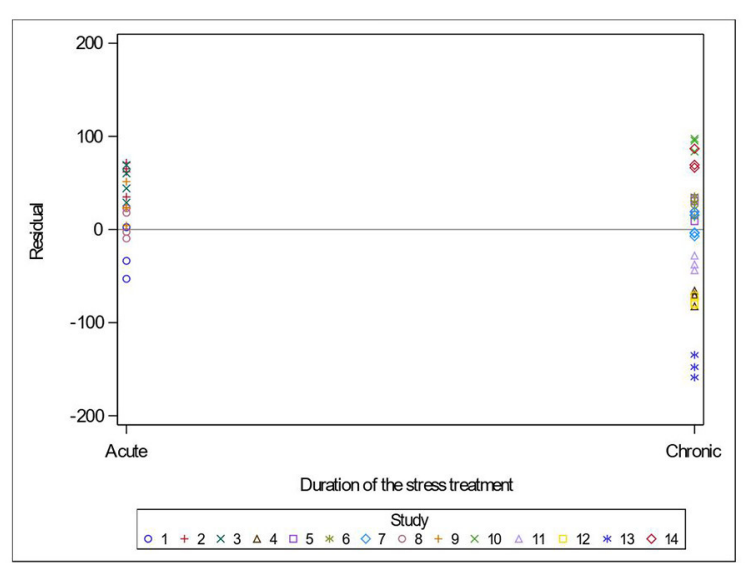

B

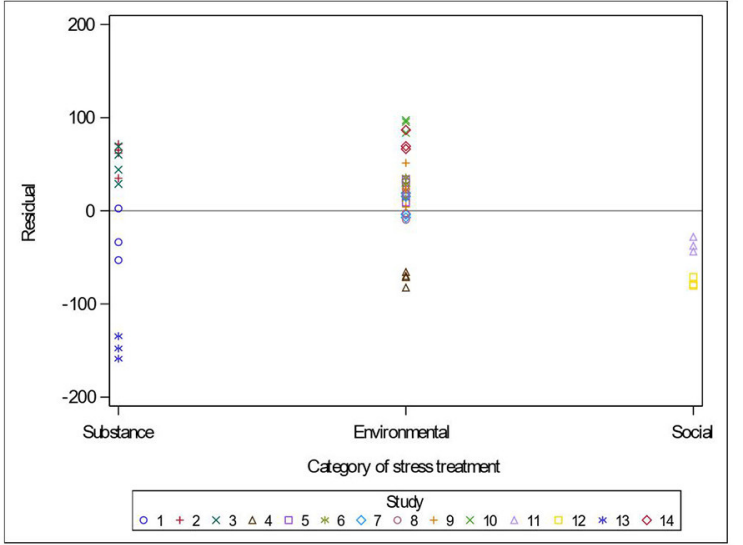

C

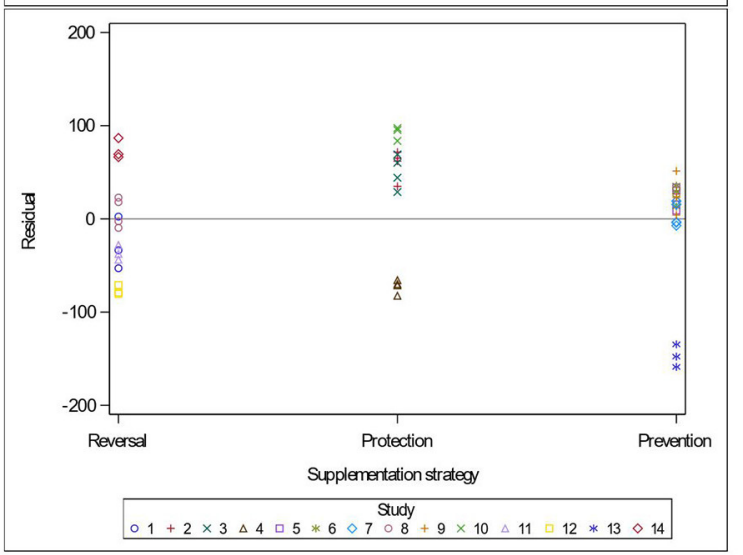

FIGURE 5 | Raw residuals of Model 3 (Supplementation*Stress) plotted against duration of the stress treatment $(\mathbf{A})$, category of stressors $(\mathbf{B})$, the treatments order $\mathbf{( C )}$ where points represent treatment means and are coded by study. has its own strengths and weaknesses in terms of predictive, face and construct validities (Powell et al., 2012). The FST is one of the most commonly used test and a valid tool to assess antidepressant effects (Kara et al., 2018) due to its low costs and high reliability (Petit-Demouliere et al., 2005). Additionally, the FST has good predictive validity, and the analogy between the FST model and the disorder affords some face validity (Willner, 1984). Nevertheless, it holds poor 


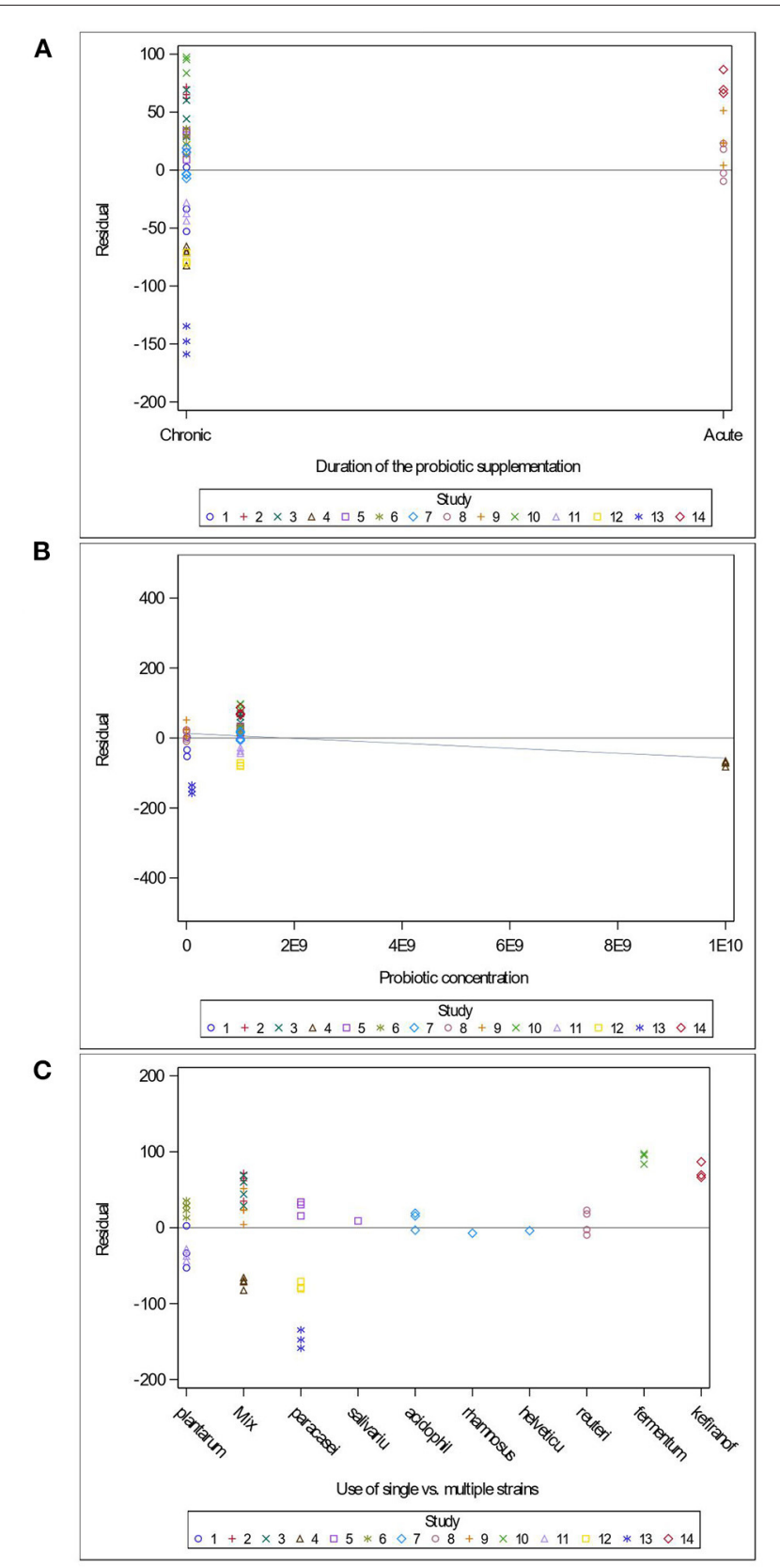

FIGURE 6 | Raw residuals of Model 3 (Supplementation*Stress) plotted against the duration of Lactobacillus-based probiotic supplementations (A), probiotic concentration (B) and the use of single or combination of bacterial strains as probiotics $(\mathbf{C})$, where points represent treatment means and are coded by study.

construct validity and lacks specificity which can be explained by high sensitivity to methodological variations (Petit-Demouliere et al., 2005). Indeed, the validity of the FST when comparing doses and various compounds might only be relevant to single experiments (Kara et al., 2018). Furthermore, FST responses can also vary greatly depending on breed of animals (PetitDemouliere et al., 2005; Powell et al., 2012). Considering the

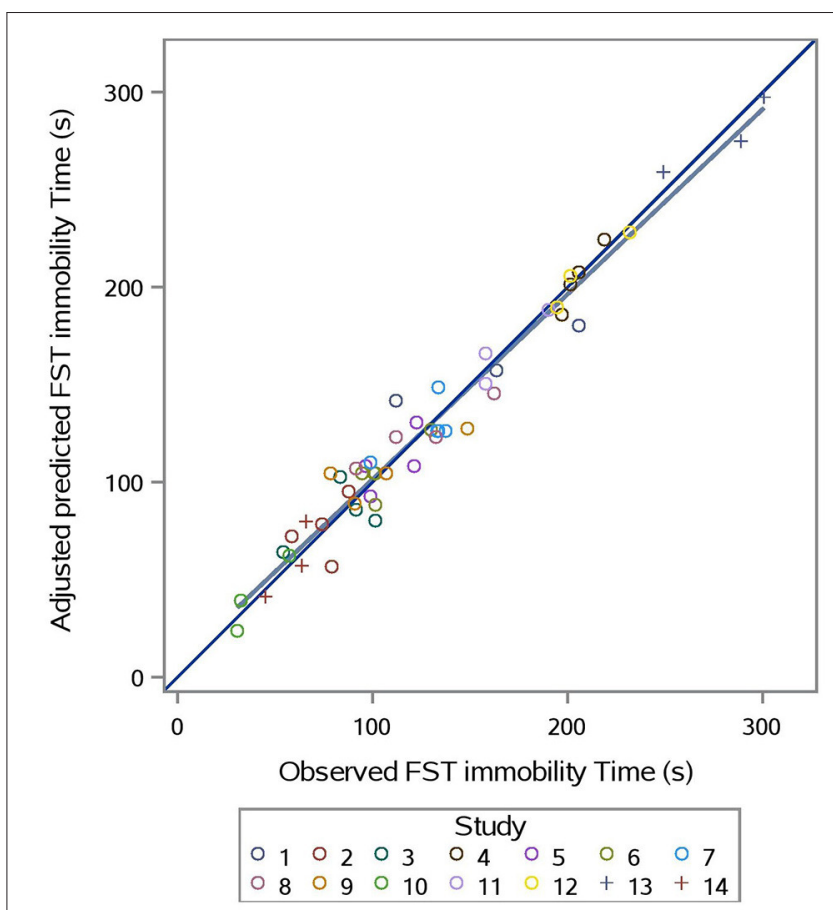

FIGURE 7 | Adjusted predicted vs. observed FST immobility time (s) for prediction equation used in Model 3 (Supplementation`Stress).

limits of this behavioral test, the suggestion that Lactobacillus may reduce depressive-like behavior under stress conditions should be interpreted with caution. In general, future research should focus on assessing a broader category of depressionassociated behaviors and physiological parameters to elucidate the true impact of probiotic therapies and their efficiency in alleviating symptoms of psychological disorders. Therefore, further, rigorous investigation in humans and animal models that better represent the physiological and behavioral hallmarks of clinical depression is needed.

Keeping the above limitations regarding FST in mind, it is nevertheless noteworthy that the current literature on gut microbiome research provides several modes of action through which effective probiotic bacteria may exert effects on psychological disorders. A complex network, including the enteric nervous system (ENS), sympathetic and parasympathetic branches of the autonomic nervous system, neuroendocrine signaling pathways, and the neuro-immune system, supports communication between the gut and the central nervous system (CNS) (Grenham et al., 2011). The gut microbiota can, therefore, influence the CNS via the immune system and ENS, especially under conditions of stress (Foster and McVey Neufeld, 2013; Huang et al., 2016; Foster et al., 2017; Wallace and Milev, 2017). Indeed, stress increases intestinal permeability (Maes et al., 2009) allowing commensal microorganisms to translocate across the intestinal mucosa and interact with both immune cells and ENS neurons. This "leaky gut" effect has been associated with major depressive disorder (MDD) (Gareau et al., 2008; Teitelbaum et al., 2008). More specifically, the increase of the 


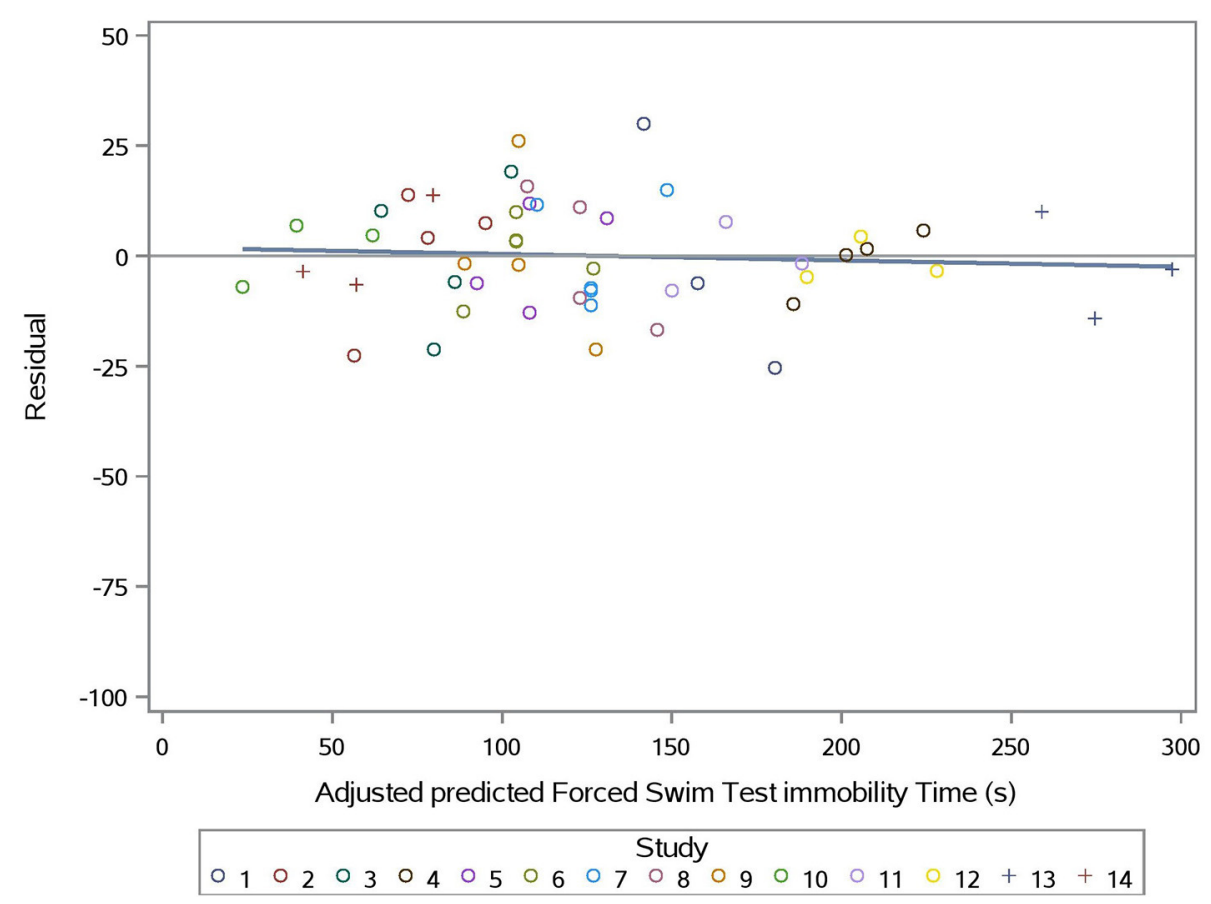

FIGURE 8 | Adjusted predicted FST immobility time (s) vs. Residual for prediction equation used in Model 3 (SupplementationStress).

pro-inflammatory mediators IL-6 and IFN- $\gamma$ in response to bacterial translocation across the gut epithelium (Foster et al., 2017) is also mirrored in depressed patients (Hodes et al., 2015). Importantly, Lactobacillus supplementation is demonstrated to suppress the pro-inflammatory response and protects against the disruption of the gut barrier by producing compounds that promote its integrity (Matsumoto et al., 2005; Lin et al., 2008; Ait-Belgnaoui et al., 2012; Kozakova et al., 2016). This group of bacteria has also been implicated in GABA receptor expression via the vagus nerve (Bravo et al., 2011), hyperpolarization of ENS neurons, influencing gut motility and pain perception via the ENS (Kunze et al., 2009), and increasing dopamine and serotonin levels (Liu et al., 2016). It is conceivable that these connections between the gut microbiota and the CNS may be disrupted in depression. Given the link between this bacterial genus and key CNS compounds, Lactobacillus supplements could be used as a tool to increase our knowledge and understanding of the interactions within the complex gut-brain network, and to, eventually, modulate its function. This putative connection to psychological disorders may also explain why Lactobacillus-based supplementation was most effective at reducing immobility time in the FST in rodents that were more stressed. It is likely that the benefits imparted to rodents that did not undergo an additional experimental stressor are limited.

Remarkably, the time and the order in which studies supplemented or stressed their population did not impact the outcome of the FST (Figure 5C). This is in agreement with Hadizadeh et al. (2019), who demonstrated that offspring of rat dams stressed during their third trimester showed marked improvements in mood disorders symptoms when supplemented with a Lactobacillus-based probiotic either as a prevention (pre-stress) or as a reversal (post-stress) treatment. Taken together with our findings, the data suggests that probiotic supplementation can be both preventive (when supplemented before a stress) and protective (when supplemented during a stress). It further suggests that Lactobacillus-based probiotic can reverse pathophysiological changes associated with some psychological disorders.

In addition, we further report that acute (i.e., short term) Lactobacillus supplementation led to over-predicting the duration of immobility in the FST (Figure 6A). While the ideal treatment duration to observe a positive impact of a probiotic is unknown (Wallace and Milev, 2017), the adherence of bacteria to epithelial cells and mucosal surfaces is a crucial criterion for probiotic selection (Duary et al., 2011). Goldin et al. (1992) reported that a Lactobacillus strain persisted in human feces for up to 4 days in $87 \%$ of individuals, but up to 7 days in $33 \%$ of the individuals. This suggests that the gut transit and retention times may ultimately influence treatment efficacy, and that individual differences between subjects can influence probiotic gut colonization. Further investigation is necessary to better assess the impact of single strain supplementation, as well as the synergistic impact of strains on stress-induced behaviors.

It is noteworthy that the non-stressed individuals of each study were not completely devoid of stress. Indeed, five studies conducted the FST based on the original protocol from Porsolt et al. (1977), which implement a pretest session $24 \mathrm{~h}$ prior to data collection ( $48 \mathrm{~h}$ in 1 study, Wei et al., 2019, Study 13). This 
TABLE 3 | Results of root mean square prediction error (rMSPE) and concordance correlation coefficient (CCC) analysis of the Model 3.

\begin{tabular}{lc}
\hline Model evaluation parameters & Model 3 \\
\hline rMSPE \%a & 9.293 \\
ECT \% ${ }^{\mathrm{b}}$ & 0.000 \\
ER \% & 0.528 \\
ED \%d & 99.47 \\
CCC $^{\mathrm{d}}$ & 0.981 \\
$\mathrm{R}^{\mathrm{f}}$ & 0.981 \\
$\mathrm{C}_{\mathrm{b}}^{\mathrm{g}}$ & 0.999 \\
$\mathrm{~V}^{\mathrm{h}}$ & 1.034 \\
$\mu^{i}$ & 0.000 \\
\hline
\end{tabular}

${ }^{a}$ Root mean square prediction error, as a percentage of observed mean.

${ }^{b}$ Error due to mean bias, as a percentage of total MSPE.

${ }^{c}$ Error due to regression, as a percentage of total MSPE.

${ }^{d}$ Error due to disturbance, as a percentage of total MSPE.

${ }^{e}$ Concordance correlation coefficient, where $C C C=r \times C_{b}$.

${ }^{f}$ Pearson correlation coefficient.

${ }^{g}$ Bias correction factor

${ }^{n}$ Scale shift.

'Location shift.

preconditioning step represents an additional stressor thought to induce a state of behavioral despair (Porsolt et al., 1977). Indeed, the pretest modifies the behavior of animals as rats develop immobility significantly faster during the second test (Porsolt et al., 1977). Thus, comparing studies that used a pretest to those that did not may yield different results. In order to account for this, the impact of the presence or absence of a pretest was tested in this meta-analysis as a covariate. However, we report no impact on the immobility outcome in the FST $(P>0.05)$. Additionally, all 14 studies included in this metaanalysis assessed animals' behavior and cognition through test batteries (between 2 and 5 tests, including the FST, Table 1). The actual order in which the tests were carried was not always specified, which implies that numerous handling procedures and stressful situations for the animals may have taken place prior to the FST. While short-term, daily handling for 5 days prior to the FST may not affect immobility time in rats (Bogdanova et al., 2013), research shows that the choice of handling method (e.g., picking up by the tail, use of tunnels or open hand voluntary approach) can induce profound variations in the mice's stress response (Hurst and West, 2010). Indeed, gentle handling reduced immobility duration in the FST compared to mice that were aversively or minimally handled (Neely et al., 2018). Unfortunately, the techniques or quality of handling is sparsely reported in publications, even in behavioral studies.

We also tested the impact of other behavioral testing, in addition to the FST, on the outcome. The number of other behavioral test appeared to significantly influence the immobility duration (data not shown). However, this consideration should be taken with caution as there was a low number of observations $(n=1)$ in the treatment groups, and the order in which the other tests were administered were not always specified. Thus, it is unknown whether these other tests happened before or after the FST, which is crucial for the interpretation of the results. We assume that only behavioral tests and the amount of handling happening before the FST would impact the result in the FST. We cannot exclude the possibility that the additional handling and behavioral testing represented yet another stressor, and it is possible that these test batteries may have masked the true changes in immobility duration in response to the intended stress treatment. Thus, all individuals in the studies would have been subjected to accumulated stress over the course of the experiments and various testing procedures, regardless of the intended stress regimen. As such, a limitation of this metaanalysis is that the non-stressed groups are not fully devoid of a stressful environment prior to the FST. Nevertheless, given that all animals in a given study underwent the same behavioral tests, the observed differences between the groups would still remain indicative of the impact of the intended stress regimen on the FST outcomes (Table 1).

Surprisingly, we report that key variables such as the age, sex, animal species and breed, Lactobacillus strain and bacterial dosage did not significantly affect the FST immobility duration in our main model. It is noteworthy that male animals are preferentially selected for animal models due to concerns about confounding contributions from the oestrous cycle, which is known to influence behavior in the FST (Bogdanova et al., 2013). The only study within the meta-analysis that employed both male and female subjects did not control for the ovarian cycle phase (Murray et al., 2019). Mice received the Lactobacillus-based probiotic treatment during their pubertal period of development (5-7 weeks of age), which may have impacted the results of that study. We report a significant sex-dependent over-prediction of the duration of immobility based on the residuals for female subjects, an observation which is absent in males (Figure 4A). This suggests that the female animals used in Murray et al. (2019) were tested during the proestrous or estrous phases as longer immobility times in the FST are observed within these periods (Bogdanova et al., 2013). This sex difference is in line with the current literature on affective disorders, where rates of depression are distinctly higher in females (Cáceda et al., 2014; Parker et al., 2014; World Health Organization, 2017). Indeed, women have higher rates of depression and often experience depression symptoms during critical reproductive periods (Noble, 2005). These sex-based significant differences highlight the need for rigorously controlled studies, including a balance between both sexes and a control of the female oestral cycle phase, to improve sex-oriented treatment of depression (Clayton and Collins, 2014; Tannenbaum et al., 2016). Similar to the unbalanced use of males and females across studies, we report that only two studies used rats (Morshedi et al., 2018; Liu et al., 2019), while the remaining studies used mice. Rodents are some of the mostwidely used animal models, but they present several speciesspecific similarities and differences within the gut microbiota (Nagpal et al., 2018). Interestingly, mice microbiota are more similar to humans than those in rats (Nagpal et al., 2018). Because of the variability of these species-specific gut microbiota signatures, it is unclear whether the same Lactobacillus-based supplementation would impact each rodent species the same way. Our meta-analysis shows that mice and rats display similar 
immobility behavior in the FST. Indeed, Figure 4B shows balanced residuals in both rats and mice. The number of publications assessing the influence of the same Lactobacillusbased supplementation in multiple species is limited. Yet, in a double-blind RCT, daily supplementation with a combination of Lactobacillus helveticus R0052 and Bifidobacterium longum displayed beneficial psychological effects both in rats and in humans (Messaoudi et al., 2011). Thus, some Lactobacillus-based supplementations are beneficial across species, despite the innate gut microbiota disparities. This hypothesis should be further tested to increase our understanding.

Behavioral responses to FST are also proposed to depend on the water temperature (Bruner and Vargas, 1994; Bogdanova et al., 2013). Indeed, rodents swimming in relatively cold water (usually $25^{\circ} \mathrm{C}$ ) compared to their core body temperature $(\sim 36-$ $37^{\circ} \mathrm{C}$ ) show increased motor activity, as well as changes in cardiovascular and neurochemistry parameters (Porsolt et al., 1979; Linthorst et al., 2008). However, the water temperature did not impact the immobility time in the FST $(P>0.05)$ within this meta-analysis as the studies used similar water temperatures $\left(22-25^{\circ} \mathrm{C}\right.$, Table 1). Similarly, the container dimensions of the FST set-up play a significant role in determining immobility behavior. When first developed, the FST tank was designed to have a depth of $15 \mathrm{~cm}$ of water, shallow enough for the rat to feel the bottom with its hind paws and tail (Porsolt et al., 1978). Numerous modified versions of the FST involve containers of various diameters and water depth which may alter swimming and immobility behavior. In the present metaanalysis, the water depth (varying between 10 and $30 \mathrm{~cm}$ ), and the container dimensions (diameter varying between 9 and $21 \mathrm{~cm}$ and depth between 25 and $50 \mathrm{~cm}$ ) did not impact the immobility time in the FST $(P>0.05)$.

To the best of the authors' knowledge, this study is the first to systematically review the effect of Lactobacillus-based probiotics on the duration of immobility in an FST in rodents by pooling the results of RCTs. Nevertheless, it is important to note a few limitations of this work. Indeed, while some population parameters, the probiotic strain, the dose and the type of stress treatment were recorded and considered in this analysis, other factors that were not considered, such as diet, may also significantly contribute to immobility in the FST. In particular, there is great individual variability between healthy gut microbiomes, which may influence responses to supplementation with particular strains of probiotics.

Additionally, the number of studies included in this analysis and the relative sample sizes of the studies are also somewhat limited. While the current analysis only showed a significant impact of Lactobacillus-based probiotics on the immobility behavior of stressed rodents, it is important to note that only two studies measured the outcomes in a non-stressed treatment group (Li et al., 2018; Murray et al., 2019), which may have influenced the results. Previously published meta-analyses have reported a positive effect of Lactobacilli on psychological symptoms of depression in healthy, non-depressed humans (Messaoudi et al., 2011; Huang et al., 2016; McKean et al., 2017) and highlights the need for more rigorous RCTs in non-stressed individuals. We also observed some large-scale differences of the mean differences between all studies (Figure 3). However, the visual assessment of funnel plots revealed no publication bias (Figures 2A,B). Finally, it should be acknowledged that the manuscript search, screening and data extracting were performed by a single reviewer and that the protocol has not been stored in a public repository. However, the steps in the review protocol are presented in the current study allowing for replication. The single reviewer received oversight from the co-authors, but it may nonetheless have impacted data quality and accuracy, including the omission of studies published in languages other than English.

\section{CONCLUSIONS}

This systematic review and meta-analysis integrate results of previous studies and support the potential role of Lactobacillusbased probiotics in mitigating stress-induced behaviors. Within the context of the FST, we report that Lactobacillus-based probiotic supplements significantly decreased the duration of immobility of stressed rodents. Further evidence from larger samples and more rigorous randomized control trials are needed to further elucidate the influence of important biological factors such as sex, animal species, duration of supplementation, Lactobacillus species, and the order of supplementation and stress treatments. The impact of Lactobacillus-based probiotic supplements under non-stressful conditions should also be evaluated in depth. The potential use of probiotics as a novel treatment or prevention strategy for major psychological disorders may aid in avoiding the stigma, latency and side effects associated with current antidepressants usage.

\section{DATA AVAILABILITY STATEMENT}

The raw data supporting the conclusions of this article will be made available by the authors, without undue reservation.

\section{AUTHOR CONTRIBUTIONS}

CM, JE, NS, and AH-M: conceptualization, methodology, and writing-review and editing. CM and JE: formal analysis and investigation. CM: writing-original draft. JE, NS, and AH-M: supervision. AH-M: funding acquisition. All authors contributed to the article and approved the submitted version.

\section{FUNDING}

This research was funded by NSERC DG grant number 400983.

\section{ACKNOWLEDGMENTS}

We would like to kindly thank Dr. Paul Forsythe for reviewing this manuscript. 


\section{REFERENCES}

Ait-Belgnaoui, A., Durand, H., Cartier, C., Chaumaz, G., Eutamene, H., Ferrier, L., et al. (2012). Prevention of gut leakiness by a probiotic treatment leads to attenuated HPA response to an acute psychological stress in rats. Psychoneuroendocrinology 37, 1885-1895. doi: 10.1016/j.psyneuen.2012. 03.024

Aizawa, E., Tsuji, H., Asahara, T., Takahashi, T., Teraishi, T., Yoshida, S., et al. (2019). Bifidobacterium and Lactobacillus counts in the gut microbiota of patients with bipolar disorder and healthy controls. Front. Psychiatry 9:730. doi: 10.3389/fpsyt.2018.00730

Almonacid, D. E., Kraal, L., Ossandon, F. J., Budovskaya, Y. V., Cardenas, J. P., Bik, E. M., et al. (2017). 16S rRNA gene sequencing and healthy reference ranges for 28 clinically relevant microbial taxa from the human gut microbiome. PLoS ONE 12:e0176555. doi: 10.1371/journal.pone.0176555

Bibby, J. M., and Toutenburg, H. (1977). Prediction and Improved Estimation in Linear Models. New-York, NY:Wiley: Chichester.

Bogdanova, O. V., Kanekar, S., D'Anci, K. E., and Renshaw, P. F. (2013). Factors influencing behavior in the forced swim test. Physiol. Behav. 118, 227-239. doi: 10.1016/j.physbeh.2013.05.012

Bravo, J. A., Forsythe, P., Chew, M. V., Escaravage, E., Savignac, H. M., Dinan, T. G., et al. (2011). Ingestion of Lactobacillus strain regulates emotional behavior and central GABA receptor expression in a mouse via the vagus nerve. Proc. Natl. Acad. Sci. U. S. A. 108, 16050-16055. doi: 10.1073/pnas.11029 99108

Briggiler-Marcó, M., Capra, M. L., Quiberoni, A., Vinderola, G., Reinheimer, J. A., and Hynes, E. (2007). Nonstarter Lactobacillus strains as adjunct cultures for cheese making: in vitro characterization and performance in two model cheeses. J. Dairy Sci. 90, 4532-4542. doi: 10.3168/jds.2007-0180

Bruner, C. A., and Vargas, I. (1994). The activity of rats in a swimming situation as a function of water temperature. Physiol. Behav. 55, 21-28. doi: 10.1016/0031-9384(94)90004-3

Cáceda, R., Moskovciak, T., Prendes-Alvarez, S., Wojas, J., Engel, A., Wilker, S. $\mathrm{H}$., et al. (2014). Gender-specific effects of depression and suicidal ideation in prosocial behaviors. PLoS ONE 9:e108733. doi: 10.1371/journal.pone.0108733

Castagné, V., Moser, P., Roux, S., and Porsolt, R. D. (2011). Rodent models of depression: forced swim and tail suspension behavioral despair tests in rats and mice. Curr. Protoc. Neurosci. 55, 8.10A.1-8.10A.14. doi: 10.1002/0471142301.ns0810as55

Cho, Y. R., Chang, J. Y., and Chang, H. C. (2007). Production of gammaaminobutyric acid (GABA) by Lactobacillus buchneri isolated from kimchi and its neuroprotective effect on neuronal cells. J. Microbiol. Biotechnol. $17,104-109$.

Clayton, J. A., and Collins, F. S. (2014). NIH to balance sex in cell and animal studies. Nature 509, 282-283. doi: 10.1038/509282a

Commons, K. G., Cholanians, A. B., Babb, J. A., and Ehlinger, D. G. (2017). The rodent forced swim test measures stress-coping strategy, not depression-like behavior. Am. Chem. Soc. 8, 955-960. doi: 10.1021/acschemneuro.7b00042

Cryan, J. F., and Holmes, A. (2005). The ascent of mouse: advances in modelling human depression and anxiety. Nat. Rev. Drug Discov. 4, 775-790. doi: $10.1038 / \mathrm{nrd} 1825$

De Kloet, E. R., and Molendijk, M. L. (2016). Coping with the forced swim stressor: towards understanding an adaptive mechanism. Neural Plast. 2016:6503162. doi: $10.1155 / 2016 / 6503162$

Dhaliwal, J., Singh, D. P., Singh, S., Pinnaka, A. K., Boparai, R. K., Bishnoi, M., et al. (2018). Lactobacillus plantarum MTCC 9510 supplementation protects from chronic unpredictable and sleep deprivation-induced behaviour, biochemical and selected gut microbial aberrations in mice. J. Appl. Microbiol. 125, 257-269. doi: $10.1111 /$ jam. 13765

Duary, R. K., Rajput, Y. S., Batish, V. K., and Grover, S. (2011). Assessing the adhesion of putative indigenous probiotic lactobacilli to human colonic epithelial cells. Indian J. Med. Res. 134, 664-671. doi: 10.4103/0971-5916.90992

Foster, J. A., and McVey Neufeld, K. A. (2013). Gut-brain axis: how the microbiome influences anxiety and depression. Trends Neurosci. 36, 305-312. doi: 10.1016/j.tins.2013.01.005

Foster, J. A., Rinaman, L., and Cryan, J. F. (2017). Stress \& the gutbrain axis: regulation by the microbiome. Neurobiol. Stress 7, 124-136. doi: 10.1016/j.ynstr.2017.03.001
Gareau, M., Silva, M., and Perdue, M. (2008). Pathophysiological mechanisms of stress-induced intestina damage. Curr. Mol. Med. 8, 274-281. doi: $10.2174 / 156652408784533760$

Gareau, M. G., Jury, J., MacQueen, G., Sherman, P. M., and Perdue, M. H. (2007). Probiotic treatment of rat pups normalises corticosterone release and ameliorates colonic dysfunction induced by maternal separation. Gut 56, 1522-1528. doi: 10.1136/gut.2006.117176

GetData Graph Digitizer. Available online at: http:/getdata-graph-digitizer.com/ (accessed February 11, 2020).

Goldin, B. R., Gorbach, S. L., Saxelin, M., Barakat, S., Gualtieri, L., and Salminen, S. (1992). Survival of Lactobacillus species (strain GG) in human gastrointestinal tract. Dig. Dis. Sci. 37, 121-128. doi: 10.1007/BF01308354

Grenham, S., Clarke, G., Cryan, J. F., and Dinan, T. G. (2011). Brain-gutmicrobe communication in health and disease. Front. Physiol. 2, 1-15. doi: 10.3389/fphys.2011.00094

Gururajan, A., Reif, A., Cryan, J. F., and Slattery, D. A. (2019). The future of rodent models in depression research. Nat. Rev. Neurosci. 20, 686-701. doi: 10.1038/s41583-019-0221-6

Guyot, P., Ades, A. E., Ouwens, M. J. N. M., and Welton, N. J. (2012). Enhanced secondary analysis of survival data: Reconstructing the data from published Kaplan-Meier survival curves. BMC Med. Res. Methodol. 12:9. doi: 10.1186/1471-2288-12-9

Hadizadeh, M., Hamidi, G. A., and Salami, M. (2019). Probiotic supplementation improves the cognitive function and the anxiety-like behaviors in the stressed rats. Iran. J. Basic Med. Sci. 22, 506-514. doi: 10.22038/ijbms.2019.339 56.8078

Heeney, D. D., Gareau, M. G., and Marco, M. L. (2018). Intestinal Lactobacillus in health and disease, a driver or just along for the ride? Curr. Opin. Biotechnol. 49, 140-147. doi: 10.1016/j.copbio.2017.08.004

Higgins, J. P. T., and Thomas, J. (2019). "Cochrane handbook for systematic reviews of interventions," in eds J. Chandler, M. Cumpston, T. Li, M. J. Page, and V. A. Welch, 2nd Edn. Wiley-Blackwell. Available online at: https:// www.wiley.com/en-gb/Cochrane+Handbook+for+Systematic+Reviews+of+ Interventions,+2nd+Edition-p- 9781119536628 (accessed April 01, 2021).

Hodes, G. E., Kana, V., Menard, C., Merad, M., and Russo, S. J. (2015). Neuroimmune mechanisms of depression. Nat. Neurosci. 18, 1386-1393. doi: $10.1038 / \mathrm{nn} .4113$

Holzapfel, W. H. (2002). Appropriate starter culture technologies for small-scale fermentation in developing countries. Int. J. Food Microbiol. 75, 197-212. doi: 10.1016/S0168-1605(01)00707-3

Holzer, P., and Farzi, A. (2014). Neuropeptides and the microbiota-gut-brain axis Europe PMC Funders Group. Adv. Exp. Med. Biol. 817, 195-219. doi: 10.1007/978-1-4939-0897-4_9

Huang, R., Wang, K., and Hu, J. (2016). Effect of probiotics on depression: a systematic review and meta-analysis of randomized controlled trials. Nutrients 8:483. doi: 10.3390/nu8080483

Hurst, J. L., and West, R. S. (2010). Taming anxiety in laboratory mice. Nat. Methods 7, 825-828. doi: 10.1038/nmeth.1500

Jang, H.-M. M., Lee, K.-E. E., and Kim, D.-H. H. (2019). The preventive and curative effects of Lactobacillus reuteri NK33 and bifidobacterium adolescentis NK98 on immobilization stress-induced anxiety/depression and colitis in mice. Nutrients 11:819. doi: 10.3390/nu11040819

Kara, N. Z., Stukalin, Y., and Einat, H. (2018). Revisiting the validity of the mouse forced swim test: Systematic review and meta-analysis of the effects of prototypic antidepressants. Neurosci. Biobehav. Rev. 84, 1-11. doi: 10.1016/j.neubiorev.2017.11.003

Kozakova, H., Schwarzer, M., Tuckova, L., Srutkova, D., Czarnowska, E., Rosiak, I., et al. (2016). Colonization of germ-free mice with a mixture of three Lactobacillus strains enhances the integrity of gut mucosa and ameliorates allergic sensitization. Cell. Mol. Immunol. 13, 251-262. doi: $10.1038 / \mathrm{cmi} .2015 .09$

Kunze, W. A., Mao, Y. K., Wang, B., Huizinga, J. D., Ma, X., Forsythe, P., et al. (2009). Lactobacillus reuteri enhances excitability of colonic AH neurons by inhibiting calcium-dependent potassium channel opening. J. Cell. Mol. Med. 13, 2261-2270. doi: 10.1111/j.1582-4934.2009.00686.x

Kutner, M. H., Nachtsheim, C. J., Neter, J., and Li, W. (2005). "Building the regression model II: diagnostics," in Applied Linear Statistical Models, ed B. Gordon (Boston: McGraw-Hill Irwin), 384-420. 
Lew, L. C., Hor, Y. Y., Yusoff, N. A. A., Choi, S. B., Yusoff, M. S. B., Roslan, N. S., et al. (2019). Probiotic Lactobacillus plantarum P8 alleviated stress and anxiety while enhancing memory and cognition in stressed adults: A randomised, double-blind, placebo-controlled study. Clin. Nutr. 38, 2053-2064. doi: $10.1016 /$ j.clnu.2018.09.010

Li, N., Wang, Q., Wang, Y., Sun, A., Lin, Y., Jin, Y., et al. (2018). Oral probiotics ameliorate the behavioral deficits induced by chronic mild stress in mice via the gut microbiota-inflammation axis. Front. Behav. Neurosci. 12:266. doi: 10.3389/fnbeh.2018.00266

Li, N., Wang, Q., Wang, Y., Sun, A., Lin, Y., Jin, Y., et al. (2019). Fecal microbiota transplantation from chronic unpredictable mild stress mice donors affects anxiety-like and depression-like behavior in recipient mice via the gut microbiota-inflammation-brain axis. Stress 22, 592-602. doi: $10.1080 / 10253890.2019 .1617267$

Liao, J. F., Hsu, C. C., Chou, G. T., Hsu, J. S., Liong, M. T., and Tsai, Y. C. (2019). Lactobacillus paracasei PS23 reduced early-life stress abnormalities in maternal separation mouse model. Benef. Microbes 10, 425-436. doi: 10.3920/BM2018.0077

Lin, L. I. (1989). A concordance correlation coefficient to evaluate reproducibility. Biometrics 45, 255-268. doi: 10.2307/2532051

Lin, Y. P., Thibodeaux, C. H., Peña, J. A., Ferry, G. D., and Versalovic, J. (2008). Probiotic Lactobacillus reuteri suppress proinflammatory cytokines via c-Jun. Inflamm. Bowel Dis. 14, 1068-1083. doi: 10.1002/ibd.20448

Linthorst, A. C. E., Flachskamm, C., and Reul, J. M. H. M. (2008). Water temperature determines neurochemical and behavioural responses to forced swim stress: an in vivo microdialysis and biotelemetry study in rats. Stress 11, 88-100. doi: 10.1080/10253890701533231

Liu, Y.-W., Ong, J. S., Gan, C. Y., Khoo, B. Y., Yahaya, S., Choi, S. B., et al. (2019). Lactobacillus fermentum PS150 showed psychotropic properties by altering serotonergic pathway during stress. J. Funct. Foods 59, 352-361. doi: $10.1016 /$ j.jff.2019.05.043

Liu, Y.-W. W., Liu, W.-H. H., Wu, C.-C. C., Juan, Y.-C. C., Wu, Y.-C. C., Tsai, H.-P. P., et al. (2016). Psychotropic effects of Lactobacillus plantarum PS128 in early life-stressed and naïve adult mice. Brain Res. 1631, 1-12. doi: 10.1016/j.brainres.2015.11.018

Lowry, C. A., Smith, D. G., Siebler, P. H., Schmidt, D., Stamper, C. E., Hassell, J. E., et al. (2016). The microbiota, immunoregulation, and mental health: implications for public health. Curr. Environ. Heal. Rep. 3, 270-286. doi: $10.1007 / \mathrm{s} 40572-016-0100-5$

Mackos, A. R., Eubank, T. D., Parry, N. M. A. A., and Bailey, M. T. (2013). Probiotic Lactobacillus reuteri attenuates the stressor-enhanced severity of Citrobacter rodentium infection. Infect. Immun. 81, 3253-3263. doi: 10.1128/IAI.00278-13

Mackos, A. R., Galley, J. D., Eubank, T. D., Easterling, R. S., Parry, N. M., Fox, J. G., et al. (2016). Social stress-enhanced severity of Citrobacter rodentiuminduced colitis is CCL2-dependent and attenuated by probiotic Lactobacillus reuteri. Mucosal Immunol. 9, 515-526. doi: 10.1038/mi.2015.81

Maes, M., Yirmyia, R., Noraberg, J., Brene, S., Hibbeln, J., Perini, G., et al. (2009). The inflammatory and neurodegenerative (IandND) hypothesis of depression: leads for future research and new drug developments in depression. Metab. Brain Dis. 24, 27-53. doi: 10.1007/s11011-008-9118-1

Marin, I. A., Goertz, J. E., Ren, T., Rich, S. S., Onengut-gumuscu, S., Farber, E., et al. (2017). Microbiota alteration is associated with the development of stress-induced despair behavior. Sci. Rep. 7:43859. doi: 10.1038/srep43859

Marquardt, P., and Spitznagel, G. (1959). [Bacterial acetylcholine production in artificial media]. Arzneimittelforschung 9, 456-465.

Matsumoto, S., Hara, T., Hori, T., Mitsuyama, K., Nagaoka, M., Tomiyasu, N., et al. (2005). Probiotic Lactobacillus-induced improvement in murine chronic inflammatory bowel disease is associated with the down-regulation of pro-inflammatory cytokines in lamina propria mononuclear cells. Clin. Exp. Immunol. 140, 417-426. doi: 10.1111/j.1365-2249.2005.02790.x

McKean, J., Naug, H., Nikbakht, E., Amiet, B., and Colson, N. (2017). Probiotics and subclinical psychological symptoms in healthy participants: a systematic review and meta-analysis. J. Altern. Comp. Med. 23, 249-258. doi: $10.1089 / \mathrm{acm} .2016 .0023$

Messaoudi, M., Lalonde, R., Violle, N., Javelot, H., Desor, D., Nejdi, A., et al. (2011). Assessment of psychotropic-like properties of a probiotic formulation (Lactobacillus helveticus R0052 and Bifidobacterium longum R0175) in rats and human subjects. Br. J. Nutr. 105, 755-764. doi: 10.1017/S0007114510004319
Molendijk, M. L., and de Kloet, E. R. (2015). Immobility in the forced swim test is adaptive and does not reflect depression. Psychoneuroendocrinology 62, 389-391. doi: 10.1016/j.psyneuen.2015.08.028

Morshedi, M., Valenlia, K. B., Hosseinifard, E. S., Shahabi, P., Abbasi, M. M., Ghorbani, M., et al. (2018). Beneficial psychological effects of novel psychobiotics in diabetic rats: the interaction among the gut, blood and amygdala. J. Nutr. Biochem. 57, 145-152. doi: 10.1016/j.jnutbio.2018.03.022

Murray, E., Sharma, R., Smith, K. B., Mar, K. D., Barve, R., Lukasik, M., et al. (2019). Probiotic consumption during puberty mitigates LPS-induced immune responses and protects against stress-induced depression- and anxiety-like behaviors in adulthood in a sex-specific manner. Brain Behav. Immun. 81, 198-212. doi: 10.1016/j.bbi.2019.06.016

Nagpal, R., Wang, S., Solberg Woods, L. C., Seshie, O., Chung, S. T., Shively, C. A., et al. (2018). Comparative microbiome signatures and short-chain fatty acids in mouse, rat, non-human primate, and human feces. Front. Microbiol. 9:2897. doi: $10.3389 /$ fmicb.2018.02897

Neely, C., Lane, C., Torres, J., and Flinn, J. (2018). The effect of gentle handling on depressive-like behavior in adult male mice: considerations for human and rodent interactions in the laboratory. Behav. Neurol. 2018:2976014. doi: $10.1155 / 2018 / 2976014$

Ng, Q. X., Peters, C., Ho, C. Y. X., Lim, D. Y. Y., Yeo, W.-S., Yih, C., et al. (2018). A meta-analysis of the use of probiotics to alleviate depressive symptoms. J. Affect. Disord. 228, 13-19. doi: 10.1016/j.jad.2017.11.063

Nistal, E., Caminero, A., Herrán, A. R., Pérez-Andres, J., Vivas, S., Ruiz de Morales, J. M., et al. (2016). Study of duodenal bacterial communities by $16 \mathrm{~S}$ rRNA gene analysis in adults with active celiac disease $v s$ non-celiac disease controls. J. Appl. Microbiol. 120, 1691-1700. doi: 10.1111/jam.13111

Noble, R. E. (2005). Depression in women. Metabolism 54, 49-52. doi: 10.1016/j.metabol.2005.01.014

Ohland, C. L., Kish, L., Bell, H., Thiesen, A., Hotte, N., Pankiv, E., et al. (2013). Effects of Lactobacillus helveticus on murine behavior are dependent on diet and genotype and correlate with alterations in the gut microbiome. Psychoneuroendocrinology 38, 1738-1747. doi: 10.1016/j.psyneuen.2013. 02.008

Özogul, F., Kuley, E., Özogul, Y., and Özogul, I. (2012). The function of lactic acid bacteria on biogenic amines production by food-borne pathogens in arginine decarboxylase broth consequently, the function of LAB strains on ammonia $(\mathrm{AMN})$ and BAs production by gram negative and positive FBP varied depending on. Food Sci. Technol. Res. 18, 795-804. doi: 10.3136/fstr.18.795

Palomar, M. M., Maldonado Galdeano, C., and Perdigón, G. (2014). Influence of a probiotic Lactobacillus strain on the intestinal ecosystem in a stress model mouse. Brain. Behav. Immun. 35, 77-85. doi: 10.1016/j.bbi.2013.08.015

Parker, G., Fletcher, K., Paterson, A., Anderson, J., and Hong, M. (2014). Gender differences in depression severity and symptoms across depressive sub-types. J. Affect. Disord. 167, 351-357. doi: 10.1016/j.jad.2014.06.018

Petit-Demouliere, B., Chenu, F., and Bourin, M. (2005). Forced swimming test in mice: a review of antidepressant activity. Psychopharmacology 177, 245-255. doi: 10.1007/s00213-004-2048-7

Porsolt, R. D., Anton, G., Blavet, N., and Jalfre, M. (1978). Behavioural despair in rats: a new model sensitive to antidepressant treatments. Eur. J. Pharmacol. 47, 379-391. doi: 10.1016/0014-2999(78)90118-8

Porsolt, R. D., Deniel, M., and Jalfre, M. (1979). Forced swimming in rats: hypothermia, immobility and the effects of imipramine. Eur. J. Pharmacol. 57, 431-436. doi: 10.1016/0014-2999(79)90507-7

Porsolt, R. D., Le Pichon, M., and Jalfre, M. (1977). Depression: a new animal model sensitive to antidepressant treatments. Nature 266, 730-732. doi: $10.1038 / 266730 \mathrm{a} 0$

Powell, T. R., Fernandes, C., and Schalkwyk, L. C. (2012). Depressionrelated behavioral tests. Curr. Protoc. Mouse Biol. 2, 119-127. doi: $10.1002 / 9780470942390 . \mathrm{mol} 10176$

Reardon, S. (2019). Depression researchers rethink popular mouse swim tests. Nature 571, 456-457. doi: 10.1038/d41586-019-02133-2

Reis, D. J., Ilardi, S. S., and Punt, S. E. W. (2018). The anxiolytic effect of probiotics: a systematic review and meta-analysis of the clinical and preclinical literature. PLoS ONE 13, 1-25. doi: 10.1371/journal.pone.0199041

Sobko, T., Huang, L., Midtvedt, T., Norin, E., Gustafsson, L. E., Norman, M., et al. (2006). Generation of NO by probiotic bacteria in the gastrointestinal tract. Free Radic. Biol. Med. 41:985-91. doi: 10.1016/j.freeradbiomed.2006.06.020 
Stanaszek, P. M., Snell, J. F., and O’Neill, J. J. (1977). Isolation, extraction, and measurement of acetylcholine from Lactobacillus plantarum. Appl. Environ. Microbiol. 34, 237-239. doi: 10.1128/AEM.34.2.237-239.1977

Stenman, L. K., Patterson, E., Meunier, J., Roman, F. J., and Lehtinen, M. J. (2020). Strain specific stress-modulating effects of candidate probiotics: a systematic screening in a mouse model of chronic restraint stress. Behav. Brain Res. 379:112376. doi: 10.1016/j.bbr.2019.112376

St-Pierre, N. R. (2001). Invited review. Integrating quantitative findings from multiple studies using mixed model methodology. J. Dairy Sci. 84, 741-755. doi: 10.3168/jds.S0022-0302(01)74530-4

Sun, Y., Geng, W., Pan, Y., Wang, J., Xiao, P., and Wang, Y. (2019). Supplementation with Lactobacillus kefiranofaciens ZW3 from Tibetan Kefir improves depression-like behavior in stressed mice by modulating the gut microbiota. Food Funct. 10, 925-937. doi: 10.1039/C8FO02096E

Tannenbaum, C., Schwarz, J. M., Clayton, J. A., De Vries, G. J., and Sullivan, C. (2016). Evaluating sex as a biological variable in preclinical research: the devil in the details. Biol. Sex Differ. 7:13. doi: 10.1186/s13293-016-0066-x

Teitelbaum, A. A., Gareau, M. G., Jury, J., Ping, C. Y., and Perdue, M. H. (2008). Chronic peripheral administration of corticotropin-releasing factor causes colonic barrier dysfunction similar to psychological stress. Am. J. Physiol. Gastrointest. Liver Physiol. 295, 452-459. doi: 10.1152/ajpgi.90210.2008

Thomas, C. M., Hong, T., van Pijkeren, J. P., Hemarajata, P., Trinh, D. V., $\mathrm{Hu}, \mathrm{W}$., et al. (2012). Histamine derived from probiotic Lactobacillus reuteri suppresses tnf via modulation of pka and erk signaling. PLOS ONE 7:31951. doi: 10.1371/journal.pone.0031951

Wallace, C. J. K., and Milev, R. (2017). The effects of probiotics on depressive symptoms in humans: a systematic review. Ann. Gen. Psychiatry 16:14. doi: 10.1186/s12991-017-0138-2

Wei, C.-L., Wang, S., Yen, J.-T., Cheng, Y.-F., Liao, C.-L., Hsu, C.-C., et al. (2019). Antidepressant-like activities of live and heat-killed Lactobacillus paracasei
PS23 in chronic corticosterone-treated mice and possible mechanisms. Brain Res. 1711, 202-213. doi: 10.1016/j.brainres.2019.01.025

WHO and FAO (2006). Probiotics in Food. Health and Nutritional Properties and Guidelines for Evaluation. Rome. Available online at: http://www.fao.org/3/aa0512e.pdf (accessed October 29, 2020).

Willner, P. (1984). The validity of animal models of depression. Psychopharmacology 83, 1-16. doi: 10.1007/BF00427414

World Health Organization (2017). Depression and Other Common Mental Disorders: Global Health Estimates. Geneva.

Yankelevitch-Yahav, R., Franko, M., Huly, A., and Doron, R. (2015). The forced swim test as a model of depressive-like behavior. J. Vis. Exp. 2015:52587. doi: $10.3791 / 52587$

Yokoyama, S., Hiramatsu, J., and Hayakawa, K. (2002). Production of $\gamma$ aminobutyric acid from alcohol distillery lees by Lactobacillus brevis IFO12005. J. Biosci. Bioeng. 93, 95-97. doi: 10.1016/S1389-1723(02)80061-5

Zhang, Z., Lv, J., Pan, L., and Zhang, Y. (2018). Roles and applications of probiotic Lactobacillus strains. Appl. Microbiol. Biotechnol. 102, 8135-8143. doi: 10.1007/s00253-018-9217-9

Conflict of Interest: The authors declare that the research was conducted in the absence of any commercial or financial relationships that could be construed as a potential conflict of interest.

Copyright (c) 2021 Mindus, Ellis, van Staaveren and Harlander-Matauschek. This is an open-access article distributed under the terms of the Creative Commons Attribution License (CC BY). The use, distribution or reproduction in other forums is permitted, provided the original author(s) and the copyright owner(s) are credited and that the original publication in this journal is cited, in accordance with accepted academic practice. No use, distribution or reproduction is permitted which does not comply with these terms. 